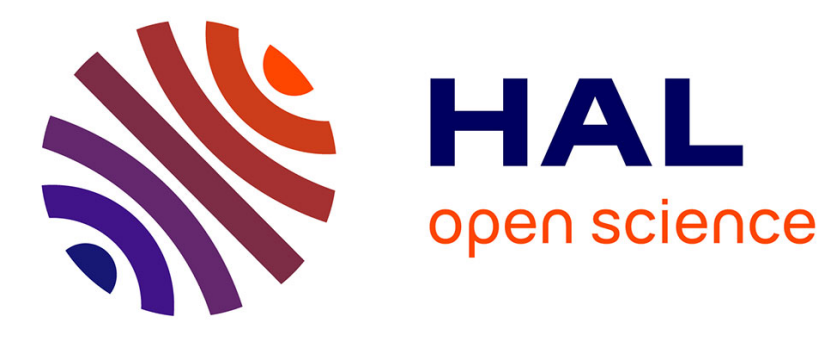

\title{
Lanthanide complexes involving multichelating TTF-based ligands
}

\author{
S. Speed, M. Feng, G. Fernandez Garcia, Fabrice Pointillart, Bertrand \\ Lefeuvre, F. Riobé, Stéphane Golhen, Boris Le Guennic, F. Totti, Y. Guyot, \\ et al.
}

\section{To cite this version:}

S. Speed, M. Feng, G. Fernandez Garcia, Fabrice Pointillart, Bertrand Lefeuvre, et al.. Lanthanide complexes involving multichelating TTF-based ligands. Inorganic Chemistry Frontiers, 2017, 4 (4), pp.604-617. 10.1039/c6qi00546b . hal-01532163

\section{HAL Id: hal-01532163 \\ https://hal-univ-rennes1.archives-ouvertes.fr/hal-01532163}

Submitted on 2 Jun 2017

HAL is a multi-disciplinary open access archive for the deposit and dissemination of scientific research documents, whether they are published or not. The documents may come from teaching and research institutions in France or abroad, or from public or private research centers.
L'archive ouverte pluridisciplinaire HAL, est destinée au dépôt et à la diffusion de documents scientifiques de niveau recherche, publiés ou non, émanant des établissements d'enseignement et de recherche français ou étrangers, des laboratoires publics ou privés. 


\title{
Lanthanide complexes Involving Multichelating TTF-based Ligands
}

\author{
S. Speed, ${ }^{a}$ M. Feng, ${ }^{\text {a }}$ G. Fernandez Garcia, ${ }^{a, c}$ F. Pointillart, ${ }^{* a}$ B. Lefeuvre, ${ }^{a}$ F. Riobé, ${ }^{b}$ S. Golhen, ${ }^{a}$ B. Le \\ Guennic, ${ }^{\text {a }}$ F. Totti, ${ }^{\mathrm{c}}$ Y. Guyot, ${ }^{\mathrm{d}}$ O. Cador, ${ }^{\mathrm{a}}$ O. Maury, ${ }^{\mathrm{b}}$ and L. Ouahab ${ }^{\mathrm{a}}$ \\ The reaction between the 2-\{TTF-fused-1H-benzimidazol-2-yl\}pyridine alkylated either with the di-(pyrazol-1-yl)-4-pyridyl \\ $\left(\mathbf{L}^{1}\right)$ or dimethyl-2,2'-bipyridine $\left(\mathbf{L}^{2}\right)$ moiety and 1 equiv. of $\mathrm{Ln}(\mathrm{hfac})_{3} \cdot 2 \mathrm{H}_{2} \mathrm{O}\left(\mathrm{Ln}^{\prime \prime \prime}=\mathrm{Dy} \mathrm{y}^{\prime \prime \prime}\right.$ and $\left.\mathrm{Yb}^{\prime \prime \prime}\right)$ leads to three dinuclear \\ complexes of formula $\left[\mathrm{Yb}_{2}(\mathrm{hfac})_{6}\left(\mathrm{~L}^{1}\right)\right] \cdot 2\left(\mathrm{CH}_{2} \mathrm{Cl}_{2}\right) \cdot \mathrm{C}_{6} \mathrm{H}_{14}(\mathbf{1})$ and $\left[\mathrm{Ln}_{2}(\mathrm{hfac})_{6}\left(\mathrm{~L}^{2}\right)\right] \cdot \mathrm{CH}_{2} \mathrm{Cl}_{2}\left(\mathrm{Ln}^{\prime \prime \prime}=\mathrm{Yb} \mathrm{b}^{\prime \prime \prime}(\mathbf{2})\right.$ and Dy $\left.\mathrm{CH}^{\prime \prime \prime}(\mathbf{3})\right)$. The X-ray \\ structures highlight square antiprism ( $\mathrm{D}_{4 \mathrm{~d}}$ symmetry) and spherical tricapped trigonal prism $\left(\mathrm{D}_{3 \mathrm{~h}}\right)$ for the eight- and nine- \\ coordinated lanthanide ions, respectively. Irradiation of the lowest-energy HOMO $\rightarrow$ LUMO ILCT absorption band induced \\ a ${ }^{2} \mathrm{~F}_{5 / 2} \rightarrow{ }^{2} \mathrm{~F}_{7 / 2} \mathrm{Yb}$-centered emission for $\mathbf{1}$ and 2. Both $\mathrm{Yb}^{\text {III }}$ ions displayed similar emissions in $\mathbf{2}$ while two distinct emissions \\ were observed and attributed to the two $\mathrm{Yb}^{\prime \prime \prime}$ ions in $\mathbf{1}$ depending on their coordination surroundings. Slow magnetic \\ relaxation is detected by dynamic magnetic measurements for 3 with a measured relaxation time $\tau_{0}=3.7(1.3) \times 10^{-7} \mathrm{~s}$ and \\ an energy barrier $\Delta=39.6(2) \mathrm{cm}^{-1}$. Taking into account the environment of both Dy'II ions in 3, it was expected that both \\ metallic centers displayed similar dynamic magnetic behavior. The latter was rationalized by ab initio CASSCF/SI-SO \\ calculations.
}

\section{Introduction}

Lanthanide ions are of great importance in molecular magnetism due to their magnetic and luminescence properties. Indeed, most of them possess a strong anisotropy and a large magnetic moment which make them good candidates for obtaining single-molecule magnets (SMMs). ${ }^{1}$ Moreover, these systems may have the ability to behave as quantum objects and act as storage units leading to potential applications such as high-density data storage devices, quantum computing or spintronics. ${ }^{2}$ Lanthanide complexes are already known to behave as SMMs with a large variety of organic ligands. ${ }^{3-5}$ In such systems the ligand plays the key role of controlling the adequate charge distribution around the lanthanide ion and so the desired axial magnetic anisotropy (Ising anisotropy) is achieved. ${ }^{6}$ As mentioned above, lanthanides are also widely studied because of their luminescence properties.

\footnotetext{
a. Institut des Sciences Chimiques de Rennes UMR 6226 CNRS-UR1, Université de Rennes 1, 35042 Rennes Cedex, France.

E-mail: fabrice.pointillart@univ-rennes1.fr, boris.leguennic@univ-rennes1.fr b. Laboratoire de Chimie de l'ENS-LYON-UMR 5182, 46 Allée d'Italie, 69364 Lyon Cedex 07.

c. Dipartimento di Chimica, Università di Firenze, Via della Lastruccia 3 Polo Scientifico, 50019 Sesto Fiorentino, Italy.

d. Université Claude Bernard Lyon 1, Institut Lumière Matière, UMR 5306 CNRSUniversité Lyon 1, 10 rue Ada Byron, 69622 Villeurbanne Cedex, France. Electronic Supplementary Information (ESI) available: Crystallographic information in CIF format, Ortep view of L1-L2 and 1-3 (Figs. S3, S5 and S7), packing views of $\mathrm{L}^{1}$ L2 (Figs. S1, S2, S4, S6 and S8), cyclic voltammetry for ligands and compounds (Fig. S9), additional data for absorption properties (Figs. S10-S15), first magnetization for 1-3 (Fig. S16). Frequency dependence of the ac susceptibility at $2 \mathrm{~K}$ of 3 (Fig. S17). Energy splitting of the ${ }^{6} \mathrm{H}_{15 / 2}$ multiplet for 3 (Fig. S18). Table of selected bond lengths (Table S1, Shape analysis (Table S2), absorption data (Table S3) and best fitted parameters with the extended Debye model (Table S4). Computed g tensors and energy splitting for compound 3 (Table S5). See DOI: 10.1039/x0xx00000x
}

This luminescence covers a wide spectroscopic range that goes from the visible to the near-infrared region with characteristic emission bands. These specific properties are used in OLEDs, ${ }^{7}$ time-resolved fluoro-immunoassays ${ }^{8}$, biosensors ${ }^{9}$ and timeresolved imaging. ${ }^{10}$ However, due to the Laporte-forbidden $f-f$ transitions, ${ }^{11}$ the emitting excited states are characterized by both long lifetimes and very weak absorption coefficients which lead to ineffective direct excitation processes in dilute solution. To overcome this disadvantage, indirect sensitization processes, via an organic chromophore, have been developed: i) triplet excited-state sensitization, ii) induced triplet metal-ligand charge transfer (MLCT) and iii) singlet excited-state with intraligand charge transfer (ILCT). ${ }^{12}$ We concentrate our attention on the ILCT process because the ligands we use preferentially, i.e. tetrathiafulvalene (TTF) functionalized derivatives, are of pushpull type. ${ }^{13}$ Considerable efforts are devoted to better understand and then predict the magnetic behaviour of lanthanide-based complexes. To that end, magnetic and luminescent coordination complexes involving lanthanides give the possibility to establish efficient correlation between these physical properties. ${ }^{14}$ In the past, it was demonstrated that TTF ligands are able to sensitize lanthanides' luminescence, ${ }^{12,15}$ generate $\mathrm{SMMs}^{16}$ and that they can combine both properties to give redox-active luminescent SMMs. ${ }^{17} \mathrm{~A}$ possible approach to enhance such effects is to design novel compounds in which more than one metal centre display slow magnetic relaxation (multi-SMM behaviour). In order to achieve this, however, it is necessary to develop new synthetic strategies to incorporate in a bridging ligand different coordination sites. Moreover it is possible to exploit different previous synthetized SMMs as "building blocks", to ensure the magnetic behaviour of each 
centre. Following this strategy, we recently used the ligand 2 \{1-[2,6-di(pyrazol-1-yl)-4-methylpyridyl]-4,5-[4,5-

bis(propylthio)-tetrathiafulvalenyl]-1 $H$-benzimidazol-2-

yl\}pyridine $\left(\mathbf{L}^{\mathbf{1}}\right)^{17}$ (Scheme 1) which presents one bis-chelating (bzip = benzimidazol-2-ylpyridyl) and one tris-chelating $[\mathrm{dpp}=$ di-(pyrazol-1-yl)-4-pyridyl] coordination site.
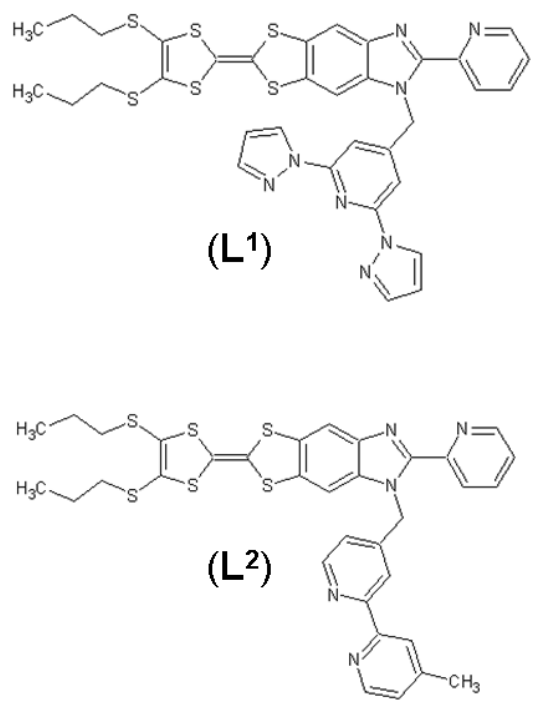

Scheme 1. Molecular structure of ligands $\mathbf{L}^{1}$ and $\mathbf{L}^{2}$.

Herein, we present the crystal structure of the abovementioned ligand $\mathbf{L}^{\mathbf{1}}$. Subsequently, to induce changes in the magnetic properties, we replace the tris-chelating moiety of $\mathbf{L}^{1}$ with a 4,4'-dimethyl-2,2'-bipyridine moiety (Mebpy) to give the 2-\{1-[4,4'-dimethyl-2,2'-bipyridyl]-4,5-[4,5-bis(propylthio)tetrathiafulvalenyl]-1 $H$-benzimidazol-2-yl\}pyridine ligand $\left(\mathbf{L}^{2}\right)$ (Scheme 1). The two dpp and Mebpy are grafted on the common 4,5-bis(propylthio)-tetrathiafulvalenyl]-1Hbenzimidazol-2-yl\}pyridine molecular skeleton which has been previously published by J. $\mathbf{W u}$ and coll. ${ }^{18}$ Ligands $\mathbf{L}^{\mathbf{2}}$ and $\mathbf{L}^{\mathbf{1}}$ as well as the resulting coordination complexes $\left[\mathrm{Yb}_{2}(\mathrm{hfac})_{6}\left(\mathrm{~L}^{\mathbf{1}}\right)\right] \cdot \mathrm{CH}_{2} \mathrm{Cl}_{2}(\mathbf{1})$ and $\left[\mathrm{Ln}_{2}(\mathrm{hfac})_{6}\left(\mathrm{~L}^{\mathbf{2}}\right)\right] \cdot \mathrm{C}_{6} \mathrm{H}_{14}\left(\mathrm{Ln}^{\prime \prime \prime}=\mathrm{Yb}(\mathbf{2})\right.$ and Dy (3)) (hfac $=1,1,1,5,5,5$-hexafluoroacetylacetonate) were characterized by X-ray diffraction, absorption spectroscopy and cyclic voltammetry. The static and dynamic magnetic properties of the complexes were also investigated. Finally, the interpretation of both absorption and magnetic properties are supported by TD-DFT and CASSCF/SI-SO calculations.

\section{Experimental section}

General Procedures and Materials.

The precursors $\operatorname{Ln}(\mathrm{hfac})_{3} \cdot 2 \mathrm{H}_{2} \mathrm{O}\left(\mathrm{Ln}^{\prime \prime \prime}=\mathrm{Dy}\right.$ and $\mathrm{Yb}$; $\mathrm{hfac}^{-}=$ $1,1,1,5,5,5$-hexafluoroacetylacetonate anion) and the ligand 2 \{1-[2,6-di(pyrazol-1-yl)-4-methylpyridyl]-4,5-[4,5bis(propylthio)-tetrathiafulvalenyl]-1H-benzimidazol-2yl\}pyridine ( $\left.\mathbf{L}^{\mathbf{1}}\right)$ were synthesized following previously reported methods. ${ }^{19,20}$ All other reagents were purchased from Aldrich Co., Ltd. and used without further purification.

Crystallization of the ligand 2-\{1-[2,6-di(pyrazol-1-yl)-4methylpyridyl]-4,5-[4,5-bis(propylthio)-tetrathiafulvalenyl]- $\mathbf{1} \boldsymbol{H}$-benzimidazol-2-yl\}pyridine $\left.\mathbf{(}^{\mathbf{1}}\right)$. Yellow single crystals of $\mathbf{L}^{\mathbf{1}}$ suitable for X-ray study were obtained by slow diffusion of $n$ hexane in a concentrated $\mathrm{CH}_{2} \mathrm{Cl}_{2}$ solution of $\mathbf{L}^{\mathbf{1}}$.

Synthesis of the ligand 2-\{1-[4,4'-dimethyl-2,2'-bipyridyl]-4,5[4,5-bis(propylthio)-tetrathiafulvalenyl]-1H-benzimidazol-2-

yl\}pyridine ( $\left(^{2}\right)$. $60 \mathrm{mg}$ of 2-(4,5-(4,5-bis(propylthio)tetrathiafulvalenyl)-1H-benzimidazol-2-yl)-pyridine ${ }^{16} \quad(0.11$ $\mathrm{mmol}$ ) and $25 \mathrm{mg}$ of $\mathrm{K}_{2} \mathrm{CO}_{3}(0.18 \mathrm{mmol}, 1.5$ equiv) were added to $5 \mathrm{~mL}$ of $\mathrm{DMF}$, and then the mixture was stirred for $30 \mathrm{~min}$ under argon. A solution of $2 \mathrm{~mL}$ of DMF containing $37 \mathrm{mg}$ of 4(Bromomethyl)-4'-methyl-2,2'-bipyridine ${ }^{21}$ (0.14 mmol, 1.25 equiv) was added, and the resulting mixture was heated at 70 ${ }^{\circ} \mathrm{C}$. After the mixture had been heated for $2 \mathrm{~h}$, additional $\mathrm{K}_{2} \mathrm{CO}_{3}$ ( $25 \mathrm{mg}, 0.18 \mathrm{mmol}, 1.5$ equiv) and 4-(Bromomethyl)-4'-methyl2,2'-bipyridine ( $15 \mathrm{mg}, 0.06 \mathrm{mmol}, 0.6$ equiv) were added. The mixture was stirred and heated overnight. The orange precipitate was filtered, washed with water $(3 \times 50 \mathrm{~mL})$, and finally dried in air. Yield: $45 \mathrm{mg}(59 \%)$. Anal. Calcd (\%) for $\mathrm{C}_{34} \mathrm{H}_{31} \mathrm{~N}_{5} \mathrm{~S}_{6}$ : C 58.17, $\mathrm{H} 4.45, \mathrm{~N}$ 9.98; found: $\mathrm{C} 58.05, \mathrm{H} 4.41, \mathrm{~N}$ 9.99. ${ }^{1} \mathrm{H}-\mathrm{NMR}\left(\mathrm{CDCl}_{3}\right): 8.53(\mathrm{~d}, 2.3 \mathrm{~Hz}, 4 \mathrm{H}), 7.82(\mathrm{~s}, 4 \mathrm{H}), 7.74$ (s, $4 \mathrm{H}), 6.46(\mathrm{~s}, 4 \mathrm{H}), 4.01(\mathrm{~s}, 4 \mathrm{H})$ and $2.38(\mathrm{~s}, 6 \mathrm{H})$. Yellow single crystals of $\mathrm{L}^{2}$ suitable for $\mathrm{X}$-ray study were obtained by slow diffusion of $n$-hexane in a concentrated solution of $\mathrm{L}^{2}$ in $\mathrm{CH}_{2} \mathrm{Cl}_{2}$. Synthesis of complexes 1-3.

$\left[\mathrm{Yb}_{\mathbf{2}}(\mathbf{h f a c})_{6}\left(\mathrm{~L}^{1}\right)\right] \cdot \mathbf{2}\left(\mathrm{CH}_{2} \mathrm{Cl}_{2}\right) \cdot \mathbf{C}_{6} \mathrm{H}_{14}$ (1). $33.2 \mathrm{mg}$ of $\mathrm{Yb}(\mathrm{hfac})_{3} \cdot 2 \mathrm{H}_{2} \mathrm{O}$ ( $0.04 \mathrm{mmol}$ ) were dissolved in $10 \mathrm{~mL}$ of $\mathrm{CH}_{2} \mathrm{Cl}_{2}$ and then added to a solution of $10 \mathrm{~mL}$ of $\mathrm{CH}_{2} \mathrm{Cl}_{2}$ containing $14.8 \mathrm{mg}$ of $\mathrm{L}^{1}(0.02$ $\mathrm{mmol})$. After $1 \mathrm{~h}$ of stirring, $40 \mathrm{~mL}$ of $n$-hexane were layered at room temperature in the dark. Slow diffusion leads to red single crystals which are suitable for $\mathrm{X}$-ray studies. Yield $39 \mathrm{mg}$ (75\%). Anal. Calcd (\%) for $\mathrm{C}_{72} \mathrm{H}_{54} \mathrm{Cl}_{4} \mathrm{Yb}_{2} \mathrm{~F}_{36} \mathrm{~N}_{8} \mathrm{O}_{12} \mathrm{~S}_{6}$ : C 33.39, $\mathrm{H} 2.09$, N 4.33; found: C 33.51, H 2.26 N, 4.39. I.R. (KBr): 2955, 2928, 2871, $2853,1653,1574,1558,1532,1506,1465,1412,1255,1207$, 1146, 1100, 1058, 975, 799, 661 and $587 \mathrm{~cm}^{-1}$.

$\left[\mathrm{Yb}_{\mathbf{2}}(\text { hfac) })_{6}\left(\mathrm{~L}^{2}\right)\right] \cdot \mathrm{CH}_{2} \mathrm{Cl}_{2}$ (2). $21 \mathrm{mg}$ of $\mathrm{Yb}(\mathrm{hfac})_{3} \cdot 2 \mathrm{H}_{2} \mathrm{O} \quad(0.025$ mmol) were dissolved in $5 \mathrm{~mL}$ of $\mathrm{CH}_{2} \mathrm{Cl}_{2}$ and then added to a solution of $5 \mathrm{~mL}$ of $\mathrm{CH}_{2} \mathrm{Cl}_{2}$ containing $10 \mathrm{mg}$ of $\mathrm{L}^{2}(0.014 \mathrm{mmol})$. After $1 \mathrm{~h}$ of stirring, $20 \mathrm{~mL}$ of $n$-hexane were layered at room temperature in the dark. Slow diffusion leads to red single crystals which are suitable for $\mathrm{X}$-ray studies. Yield $20 \mathrm{mg}$ (70\%). Anal. Calcd (\%) for $\mathrm{C}_{65} \mathrm{H}_{39} \mathrm{Cl}_{2} \mathrm{~F}_{36} \mathrm{Yb}_{2} \mathrm{~N}_{5} \mathrm{O}_{12} \mathrm{~S}_{6}$ : $\mathrm{C} 32.87, \mathrm{H} 1.65, \mathrm{~N}$ 2.95; found: C 32.99, H 1.76 N, 2.94. I.R. (KBr): 2955, 2870, 2852, $1653,1528,1497,1465,1410,1256,1209,1135,1100,1058$, $976,798,660$ and $587 \mathrm{~cm}^{-1}$.

$\left[\mathrm{Dy}_{\mathbf{2}}(\text { hfac) })_{6}\left(\mathbf{L}^{2}\right)\right] \cdot \mathbf{C H}_{2} \mathrm{Cl}_{2}$ (3). $21 \mathrm{mg}$ of Dy(hfac) $)_{3} \cdot 2 \mathrm{H}_{2} \mathrm{O} \quad(0.025$ mmol) were dissolved in $5 \mathrm{~mL}$ of $\mathrm{CH}_{2} \mathrm{Cl}_{2}$ and then added to a solution of $5 \mathrm{~mL}$ of $\mathrm{CH}_{2} \mathrm{Cl}_{2}$ containing $8 \mathrm{mg}$ of $\mathrm{L}^{2}(0.011 \mathrm{mmol})$. After $1 \mathrm{~h}$ of stirring, $20 \mathrm{~mL}$ of $n$-hexane were layered at room temperature in the dark. Slow diffusion leads to red single crystals which are suitable for $\mathrm{X}$-ray studies. Yield $18 \mathrm{mg}$ (70\%). Anal. Calcd (\%) for $\mathrm{C}_{65} \mathrm{H}_{39} \mathrm{Cl}_{2} \mathrm{~F}_{36} \mathrm{Dy}_{2} \mathrm{~N}_{5} \mathrm{O}_{12} \mathrm{~S}_{6}$ : C 33.16, $\mathrm{H} 1.67, \mathrm{~N}$ 2.97; found: C 33.09, H 1.72 N, 2.94. I.R. (KBr): 2956, 2872, 2852, $1654,1528,1497,1464,1409,1255,1209,1135,1100,1057$, $978,799,660$ and $587 \mathrm{~cm}^{-1}$.

Crystallography. Single crystals of $\mathbf{L}^{\mathbf{1}}$ and $\mathbf{L}^{\mathbf{2}} ; \mathbf{1}$-3 were mounted on a APEXII Bruker-AXS diffractometer for data collection (MoK $\alpha$ radiation source, $\lambda=0.71073 \AA \AA)$, from the Centre de 
Diffractométrie (CDIFX), Université de Rennes 1, France. Structures were solved with a direct method using the SIR-97 program and refined with a full matrix least-squares method on $\mathrm{F}^{2}$ using the SHELXL-97 program ${ }^{22}$. Crystallographic data are summarized in Table 1. Complete crystal structure results as a $\mathrm{CIF}$ file including bond lengths, angles, and atomic coordinates are deposited as Supporting Information (CCDC numbers: 1515791-1515795 for $\mathbf{L}^{\mathbf{1}}, \mathbf{L}^{\mathbf{2}}, \mathbf{2}, \mathbf{3}$ and $\mathbf{1}$ respectively).

Physical Measurements. The elemental analyses of the compounds were performed at the Centre Régional de Mesures Physiques de l'Ouest, Rennes. ${ }^{1} \mathrm{H}$ NMR was recorded on a Bruker Ascend 400 spectrometer. Chemical shifts are reported in parts per million referenced to TMS for ${ }^{1} \mathrm{H}$ NMR. Cyclic voltammetry was carried out in $\mathrm{CH}_{2} \mathrm{Cl}_{2}$ solution, containing 0.1 $\mathrm{M} \mathrm{N}\left(\mathrm{C}_{4} \mathrm{H}_{9}\right)_{4} \mathrm{PF}_{6}$ as supporting electrolyte. Voltammograms were recorded at $100 \mathrm{mVs}^{-1}$ at a platinum disk electrode. The potentials were measured versus a saturated calomel electrode (SCE). Absorption spectra were recorded on a Varian Cary 5000 UV-Visible-NIR spectrometer equipped with an integration sphere. The luminescence spectra were measured using a Horiba-Jobin Yvon Fluorolog- $3^{\circledR}$ spectrofluorimeter, equipped with a three slit double grating excitation and emission monochromator with dispersions of $2.1 \mathrm{~nm} / \mathrm{mm}$ (1200 grooves $/ \mathrm{mm}$ ). The steady-state luminescence was excited by unpolarized light from a $450 \mathrm{~W}$ xenon $\mathrm{CW}$ lamp and detected at a $90^{\circ}$ angle for diluted solution measurements and for solid state measurement by a red-sensitive Hamamatsu R928 photomultiplier tube. Spectra were reference corrected for both the excitation source light intensity variation (lamp and grating) and the emission spectral response (detector and grating). Near infra-red spectra were recorded at a $90^{\circ}$ angle using a liquid nitrogen cooled, solid indium/gallium/arsenic detector (850-1600 nm). The luminescence decay of ytterbium complexes was determined using a home-made set-up. The

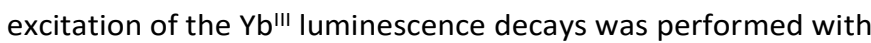
an optical parametric oscillator from EKSPLA NT342, pumped with a pulsed frequency tripled YAG:Nd laser. The pulse duration was $6 \mathrm{~ns}$ at $10 \mathrm{~Hz}$ repetition rate. The detection was performed by a R1767 Hamamatsu photomultiplier through a Jobin-Yvon monochromator equipped with a $1 \mu \mathrm{m}$ blazed grating. The signal was visualized and averaged with a Lecroy digital oscilloscope LT342. The dc magnetic susceptibility measurements were performed on solid polycrystalline samples with a Quantum Design MPMS-XL SQUID magnetometer between 2 and $300 \mathrm{~K}$ in applied magnetic field of $0.2 \mathrm{~T}$ for temperatures of $2-20 \mathrm{~K}$ and $1 \mathrm{~T}$ for temperatures of 20-300 K. These measurements were all corrected for the diamagnetic contribution as calculated with Pascal's constants. Computational Details. DFT geometry optimizations and TDDFT excitation energy calculations of the ligands $\mathbf{L}^{\mathbf{1}}$ and $\mathbf{L}^{\mathbf{2}}$ and the $Y^{\prime \prime I}$ analogues of the corresponding complexes were carried out with the Gaussian 09 (revision A.02) package ${ }^{23}$ employing the PBEO hybrid functional. ${ }^{24}$ The "Stuttgart/Dresden" basis sets and effective core potentials were used to describe the yttrium atom, ${ }^{25}$ whereas all other atoms were described with the SVP basis sets. ${ }^{26}$ The first 80 monoelectronic excitations were calculated. In all steps, a modelling of bulk solvent effects (solvent $=$ dichloromethane) was included through the Polarisable Continuum Model (PCM), ${ }^{27}$ using a linear-response non-equilibrium approach for the TD-DFT step. ${ }^{28}$ Molecular orbitals were sketched using the Gabedit graphical interface. ${ }^{29}$ Wavefunction-based calculations were carried out for complex $\mathbf{3}$ by using the SA-CASSCF/RASSI-SO approach, as implemented in the MOLCAS quantum chemistry package (versions 8.0). ${ }^{30}$ To simplify the calculations and concentrate on the local magnetic properties, $\mathbf{3}$ has been treated as two independent Dy"II-based fragments. The first one was composed by the Dy1 ion and the 4,5-bis(propylthio)-tetrathiafulvalenyl]- $1 \mathrm{H}$-benzimidazol-2-

yl\}pyridine moiety while the second fragment was constituted of the Dy2 ion and the dimethyl-2,2'-bipyridine moiety. Relativistic effects are treated in two steps on the basis of the Douglas-Kroll Hamiltonian: i) the scalar terms were included in the basis-set generation and were used to determine the spinfree wavefunctions and energies in the complete active space self-consistent field (CASSCF) method, ${ }^{31}$ and the spin-orbit coupling was added within the restricted-active-space-stateinteraction (RASSI-SO) method, which uses the spin-free wavefunctions as basis states. ${ }^{32}$ The resulting wavefunctions and energies are used to compute the magnetic properties and g-tensors of the lowest states from the energy spectrum by using the pseudo-spin $S=1 / 2$ formalism in the SINGLE-ANISO routine. ${ }^{33}$ Cholesky decomposition of the bielectronic integrals was employed to save disk space and speed-up the calculations. ${ }^{34}$ The atomic positions were extracted from the Xray crystal structures. Only the positions of the $\mathrm{H}$ atoms were optimized using the DFT protocol described previously. The active space of the self-consistent field (CASSCF) method consisted of the nine $4 \mathrm{f}$ electrons of the Dy'll ion spanning the seven $4 f$ orbitals, i.e. CAS $(9,7)$ SCF. State-averaged CASSCF calculations were performed for all of the sextets ( 21 roots), all of the quadruplets (224 roots), and 300 out of the 490 doublets of the Dy'II ion. 21 sextets, 128 quadruplets, and 107 doublets were mixed through spin-orbit coupling in RASSI-SO. All atoms were described by ANO-RCC basis sets. ${ }^{35}$ The following contractions were used: [8s7p4d3f2g1h] for Dy, [4s3p2d] for the $O$ directly coordinated to $D y,[3 s 2 p]$ for other $O$ atoms; [3s2p1d] for the $\mathrm{N}$ atoms; [4s3p] for the $\mathrm{S}$ atoms, [3s2p] for the $\mathrm{C}$ and $\mathrm{F}$ atoms and $[2 \mathrm{~s}]$ for the $\mathrm{H}$ atoms.

\section{Results and discussion}

\section{Crystal structure analysis}

$\mathbf{L}^{\mathbf{1}}$. This ligand crystallizes in the $\mathrm{P}-\mathbf{1}\left(\mathrm{N}^{\circ} 2\right)$ triclinic space group (Table 1 ). The asymmetric unit is composed by only one molecule of $\mathbf{L}^{\mathbf{1}}$ (Fig. 1). The neutrality of $\mathbf{L}^{\mathbf{1}}$ is confirmed by the central C9-C10 bond length of 1.318(10) A. The TTF core adopts a planar conformation with the orientation of the dpp moiety almost perpendicular to it with an angle of $86.42^{\circ}$. The crystal packing reveals a regular one-dimensional stacking along the a

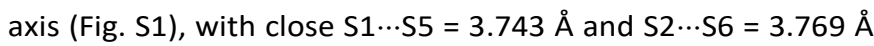
contacts. 
Table 1. $X$-ray crystallographic data for the ligands $\mathbf{L}^{1}$ and $\mathbf{L}^{2}$, and complexes 1-3.

\begin{tabular}{|c|c|c|c|}
\hline Compounds & $\mathbf{L}^{1}$ & $\mathbf{L}^{2}$ & {$\left[\mathrm{Yb}_{2}(\mathrm{hfac})_{6}\left(\mathbf{L}^{\mathbf{1}}\right)\right] \cdot 2 \mathrm{CH}_{2} \mathrm{Cl}_{2} \cdot \mathrm{C}_{6} \mathrm{H}_{14}(\mathbf{1})$} \\
\hline Formula & $\mathrm{C}_{34} \mathrm{H}_{30} \mathrm{~N}_{8} \mathrm{~S}_{6}$ & $\mathrm{C}_{34} \mathrm{H}_{31} \mathrm{~N}_{5} \mathrm{~S}_{6}$ & $\mathrm{C}_{72} \mathrm{H}_{54} \mathrm{Cl}_{4} \mathrm{Yb}_{2} \mathrm{~F}_{36} \mathrm{~N}_{8} \mathrm{O}_{12} \mathrm{~S}_{6}$ \\
\hline $\mathrm{M} / \mathrm{g} \cdot \mathrm{mol}^{-1}$ & 743.0 & 702.0 & 2587.5 \\
\hline Crystal system & Triclinic & Triclinic & Monoclinic \\
\hline Space group & $\mathrm{P}-1\left(\mathrm{~N}^{\circ} 2\right)$ & $\mathrm{P}-1\left(\mathrm{~N}^{\circ} 2\right)$ & $\mathrm{P} 2_{1} / \mathrm{n}\left(\mathrm{N}^{\circ} 14\right)$ \\
\hline \multirow[t]{6}{*}{ Cell parameters } & $\mathrm{a}=8.184(9) \AA$ & $\mathrm{a}=8.1794(14) \AA$ & $\mathrm{a}=22.2682(13) \AA$ \\
\hline & $\mathrm{b}=13.719(15) \AA$ & $\mathrm{b}=14.562(2) \AA$ & $\mathrm{b}=12.7174(8) \AA$ \\
\hline & $c=16.857(16) \AA$ & $\mathrm{c}=14.923(3) \AA$ & $c=33.6141(16) \AA$ \\
\hline & $\alpha=112.03(5)^{\circ}$ & $\alpha=111.939(8)^{\circ}$ & \\
\hline & $\beta=90.19(4)^{\circ}$ & $\beta=95.390(6)^{\circ}$ & $\beta=100.365(2)^{\circ}$ \\
\hline & $\gamma=106.24(5)^{\circ}$ & $\gamma=96.410(7)^{\circ}$ & \\
\hline Volume / $\AA^{3}$ & $1672(3)$ & $1620.6(5)$ & $9364.0(9)$ \\
\hline Cell formula units & 2 & 2 & 4 \\
\hline $\mathrm{T} / \mathrm{K}$ & $150(2)$ & $150(2)$ & $150(2)$ \\
\hline Diffraction reflection & $2.63 \leq 2 \theta \leq 56.07$ & $2.97 \leq 2 \theta \leq 55.44$ & $2.04 \leq 2 \theta \leq 55.12$ \\
\hline$\rho_{\text {calc }}$, g.cm $\mathrm{cm}^{-3}$ & 1.476 & 1.439 & 1.835 \\
\hline$\mu, \mathrm{mm}^{-1}$ & 0.450 & 0.457 & 2.365 \\
\hline Number of reflections & 7452 & 13955 & 82503 \\
\hline Independent reflections & 7452 & 7348 & 21285 \\
\hline $\mathrm{Fo}^{2}>2 \sigma(\mathrm{Fo})^{2}$ & 3257 & 3151 & 16892 \\
\hline Number of variables & 434 & 408 & 1205 \\
\hline $\mathrm{R}_{\mathrm{int}}, \mathrm{R}_{1}, \mathrm{w} \mathrm{R}_{2}$ & $0.1738,0.0776,0.1412$ & $0.0956,0.0807,0.1632$ & $0.0703,0.1173,0.2927$ \\
\hline Compounds & {$\left[\mathrm{Yb}_{2}(\mathrm{hfac})_{6}\left(\mathbf{L}^{2}\right)\right] \cdot \mathrm{CH}_{2} \mathrm{Cl}_{2}(\mathbf{2})$} & {$\left[\mathrm{Dy}_{2}(\mathrm{hfac})_{6}\left(\mathbf{L}^{2}\right)\right] \cdot \mathrm{CH}_{2} \mathrm{Cl}_{2}(\mathbf{3})$} & \\
\hline Formula & $\mathrm{C}_{65} \mathrm{H}_{39} \mathrm{Cl}_{2} \mathrm{Yb}_{2} \mathrm{~F}_{36} \mathrm{~N}_{5} \mathrm{O}_{12} \mathrm{~S}_{6}$ & $\mathrm{C}_{65} \mathrm{H}_{39} \mathrm{Cl}_{2} \mathrm{Dy}_{2} \mathrm{~F}_{36} \mathrm{~N}_{5} \mathrm{O}_{12} \mathrm{~S}_{6}$ & \\
\hline $\mathrm{M} / \mathrm{g} \cdot \mathrm{mol}^{-1}$ & 2375.4 & 2354.3 & \\
\hline Crystal system & Triclinic & Triclinic & \\
\hline Space group & $\mathrm{P}-1\left(\mathrm{~N}^{\circ} 2\right)$ & $\mathrm{P}-1\left(\mathrm{~N}^{\circ} 2\right)$ & \\
\hline \multirow[t]{6}{*}{ Cell parameters } & $\mathrm{a}=12.5259(6) \AA$ & $\mathrm{a}=12.5468(7) \AA$ & \\
\hline & $\mathrm{b}=16.3942(9) \AA$ & $\mathrm{b}=16.3551(9) \AA$ & \\
\hline & $c=22.1956(12) \AA$ & $\mathrm{c}=22.1813(11) \AA$ & \\
\hline & $\alpha=87.532(2)^{\circ}$ & $\alpha=87.829(2)^{\circ}$ & \\
\hline & $\beta=88.446(2)^{\circ}$ & $\beta=88.851(2)^{\circ}$ & \\
\hline & $\gamma=74.477(2)^{\circ}$ & $\gamma=74.949(2)^{\circ}$ & \\
\hline Volume / $\AA^{3}$ & $4387.0(4)$ & $4392.1(4)$ & \\
\hline Cell formula units & 2 & 2 & \\
\hline $\mathrm{T} / \mathrm{K}$ & $150(2)$ & $150(2)$ & \\
\hline Diffraction reflection & $1.84 \leq 2 \theta \leq 55.08$ & $1.84 \leq 2 \theta \leq 55.09$ & \\
\hline$\rho_{\text {calc }}$, g.cm ${ }^{-3}$ & 1.798 & 1.780 & \\
\hline$\mu, \mathrm{mm}^{-1}$ & 2.456 & 2.025 & \\
\hline Number of reflections & 54840 & 68575 & \\
\hline Independent reflections & 19960 & 19845 & \\
\hline $\mathrm{Fo}^{2}>2 \sigma(\mathrm{Fo})^{2}$ & 14598 & 16106 & \\
\hline Number of variables & 1155 & 1187 & \\
\hline $\mathrm{R}_{\mathrm{int}}, \mathrm{R}_{1}, \mathrm{wR}_{2}$ & $0.0546,0.0577,0.1541$ & $0.0357,0.0496,0.1335$ & \\
\hline
\end{tabular}

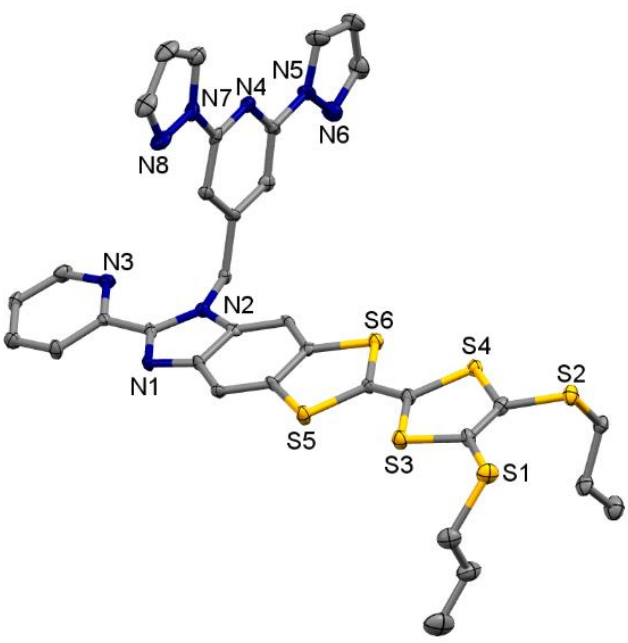

Fig. 1 ORTEP view of $\mathbf{L}^{\mathbf{1}}$. Thermal ellipsoids are drawn at 30\% probability. Hydrogen atoms are omitted for clarity.

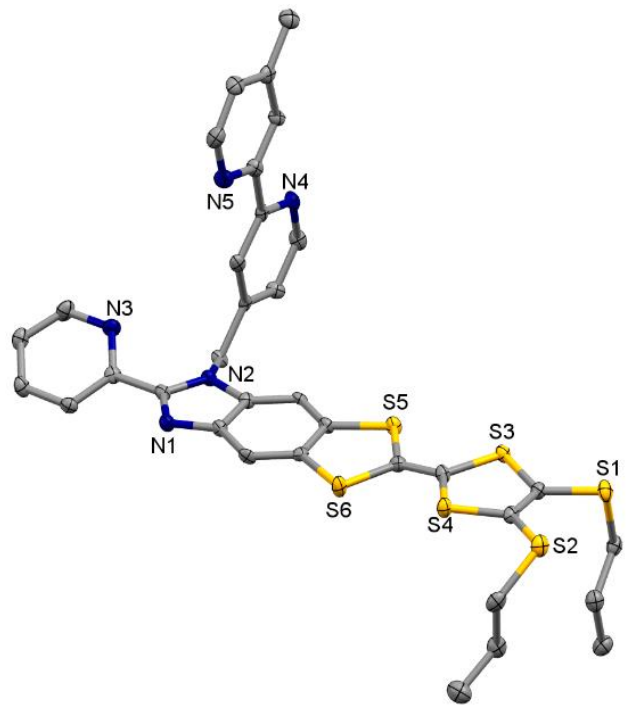

Fig. 2 ORTEP view of $\mathbf{L}^{2}$. Thermal ellipsoids are drawn at 30\% probability. Hydrogen atoms are omitted for clarity. 
$\mathbf{L}^{\mathbf{2}}$. This ligand also crystallizes in the $\mathrm{P}-1\left(\mathrm{~N}^{\circ} 2\right)$ triclinic space group (Table 1 ). The asymmetric unit is composed by only one molecule of $\mathbf{L}^{\mathbf{2}}$ (Fig. 2 ). As for $\mathbf{L}^{\mathbf{1}}$, the neutrality of $\mathbf{L}^{\mathbf{2}}$ is confirmed by the central C9-C10 bond length of 1.338(8) A. The TTF core adopts a planar conformation with the orientation of the Mebpy moiety almost perpendicular to it with an angle of 88.170. The crystal packing reveals a regular one-dimensional stacking along the a axis (Fig. S2), with S2 $\cdots \mathrm{S} 6=3.693 \AA$ contacts.

$\left[\mathrm{Yb}_{2}(\mathrm{hfac})_{6}\left(\mathrm{~L}^{1}\right)\right] \cdot 2 \mathrm{CH}_{2} \mathrm{Cl}_{2} \cdot \mathrm{C}_{6} \mathrm{H}_{14}$ (1). Compound 1 crystallizes in the $\mathrm{P} 21 / \mathrm{n}\left(\mathrm{N}^{\circ} 14\right)$ monoclinic space group (Table 1$)$. The asymmetric unit is composed of two $\mathrm{Yb}(\mathrm{hfac})_{3}$ moieties, one $\mathbf{L}^{\mathbf{1}}$ ligand, a $n$-hexane and two dichloromethane molecules of crystallization. An ORTEP view is depicted in the Fig. S3. The Yb1 ion is surrounded by six oxygen atoms that belong to three hfac ligands and two nitrogen atoms from the bis-chelating coordination site (bzip moiety) of $\mathbf{L}^{\mathbf{1}}$ (Fig. 3). The $\mathrm{Yb} 2$ ion is surrounded by six oxygen atoms that belong to three hfac ligands and three nitrogen atoms from the tris-chelating coordination site (dpp moiety) of $\mathbf{L}^{\mathbf{1}}$.

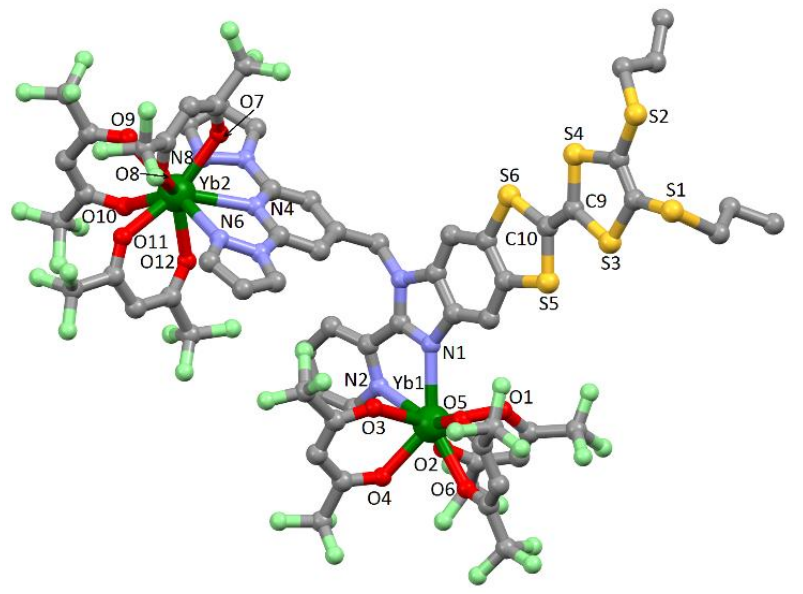

Fig. 3 Molecular structure of $\mathbf{1}$. Hydrogen atoms and both dichloromethane and $n$ hexane molecules of crystallization are omitted for clarity.

The average $\mathrm{Yb}-\mathrm{O}$ distances are shorter $(2.314(10) \AA)$ than the average Yb-N distances (2.491(12) Å) (Table S1) due to the oxophilic character of the lanthanide, as usually observed.

The arrangement of the ligands leads to a distorted square antiprism ( $D_{4 d}$ symmetry) and spherical tricapped trigonal prism ( $D_{3 h}$ symmetry) as coordination polyhedra for $\mathrm{Yb} 1$ and $\mathrm{Yb} 2$ ions, respectively. The distortion is visualized by continuous shape measures performed with SHAPE 2.1 (Table S2). ${ }^{36}$

The central $C=C$ bond of the TTF core is equal to $1.373(18) \AA$ which confirms the neutral form of $\mathbf{L}^{1}$. The shortest S $\cdots \mathrm{S}$

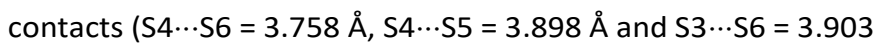
$\AA$ ) lead to the formation of isolated dimers head-to-tail donors (Fig. S4), separated by $\mathrm{Yb}(\mathrm{hfac})_{3}$ moieties. The shortest intraand intermolecular $\mathrm{Yb}-\mathrm{Yb}$ distances are $10.759 \AA$ and $10.772 \AA$ (Yb1-Yb2), respectively.

[ $\left.\operatorname{Ln}_{2}(\text { hfac) })_{6}\left(\mathrm{~L}^{2}\right)\right] \cdot \mathrm{CH}_{2} \mathrm{Cl}_{2}$ ( $\left.\mathrm{Ln}=\mathrm{Yb}(2), \mathrm{Dy}(3)\right)$. Compounds $\mathbf{2}$ and 3 are isostructural and so only one description will be provided for both compounds. The values for $\mathbf{3}$ will be given in brackets. Both complexes crystallize in the $\mathrm{P}-1\left(\mathrm{~N}^{\circ} 2\right)$ triclinic space group (Table 1).

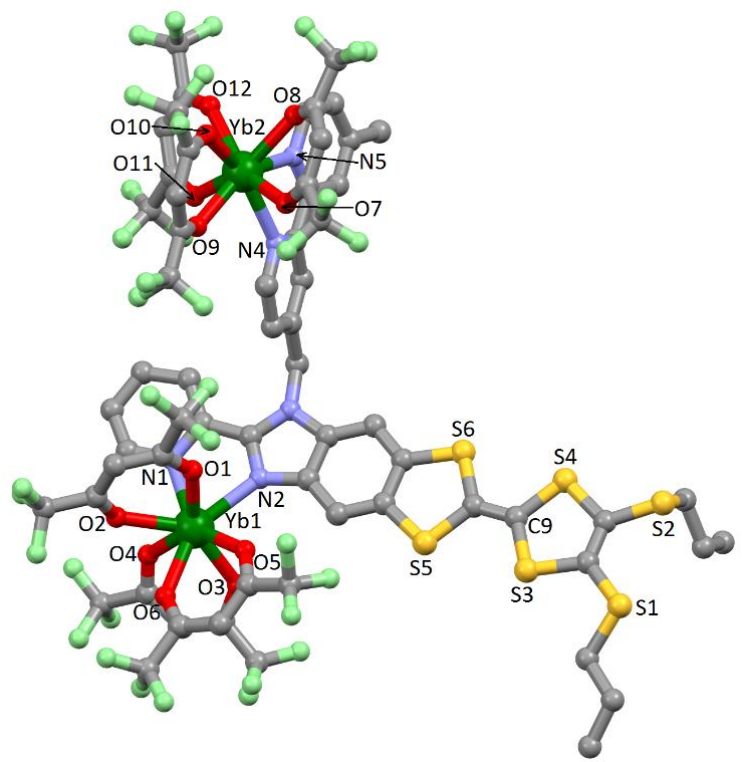

Fig. 4 Molecular structure of 2. Hydrogen atoms and dichloromethane molecule of crystallization are omitted for clarity.

The asymmetric unit is composed of two $\operatorname{Ln}(\mathrm{hfac})_{3}$ moieties, one $\mathbf{L}^{2}$ ligand and a dichloromethane molecule of crystallization (Figs. 4, S5 and S7). The X-ray structure reveals that the two coordination sites of $\mathbf{L}^{\mathbf{2}}$ are coordinated to a $\operatorname{Ln}(\mathrm{hfac})_{3}$ moiety. The $L{ }^{\prime \prime \prime}$ ions are surrounded by six oxygen atoms that belong to three hfac- ligands and two nitrogen atoms that belong to the bis-chelating coordination sites (the Mebpy or the bzip moieties). Selected bond lengths are reported in Table S1. The average Ln-O distances 2.296(5) $\AA$ [(2.337(4) $\AA$ )] are shorter than the average Ln-N distances 2.468(5) $\AA$ [(2.517(5) $\AA$ )] due to the usually observed oxophilic character of the lanthanide. The arrangement of the ligands leads to a distorted square antiprism ( $D_{4 d}$ symmetry) as coordination polyhedra for both $\mathrm{Ln}$ ions of the molecule (Table S2). The central $\mathrm{C}=\mathrm{C}$ bond of the TTF core is equal to $1.342(9) \AA[1.348(7) \AA]$ which confirms the neutral form of $\mathbf{L}^{\mathbf{2}}$. The crystal packing reveals the formation of

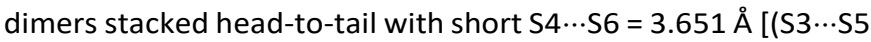
$=3.656 \AA)$ ] contacts arranged as a one-dimensional network and isolated one another by $\mathrm{Ln}(\mathrm{hfac})_{3}$ moieties (Figs. S6 and S8). The shortest intra- and intermolecular Ln-Ln distances are 10.426 ̊ [10.479 ̊] and 10.030 ̊ [8.410 ̊̊] (Yb1-Yb2 / Dy2-Dy2), respectively.

Electrochemical Properties. The redox properties of the ligands $\mathbf{L}^{\mathbf{1}}$ and $\mathbf{L}^{\mathbf{2}}$ as well as the related complexes $\mathbf{1 - 3}$ are investigated by cyclic voltammetry (Fig. S9), the values of the oxidation potentials are listed in Table 2. The cyclic voltammograms for the free ligands, $\mathbf{L}^{\mathbf{1}}$ and $\mathbf{L}^{\mathbf{2}}$, show two mono-electronic oxidations at about $0.50 \mathrm{~V}$ for the first oxidation and about $0.90 \mathrm{~V}$ for the second oxidation, corresponding to the formation of a radical cation and a dication TTF fragment, respectively (Fig. S9). 
Table 2. Oxidation potentials ( $\mathrm{V}$ vs SCE, $\mathrm{nBu}_{4} \mathrm{NPF}_{6}, 0.1 \mathrm{M}$ in $\mathrm{CH}_{2} \mathrm{Cl}_{2}$ at $100 \mathrm{mV} \cdot \mathrm{s}^{-1}$ ) of the ligands $\mathrm{L}^{\mathbf{1}}$ and $\mathrm{L}^{\mathbf{2}}$ and the complexes $\mathbf{1 - 3}$.

\begin{tabular}{|l|l|l|}
\hline & $\mathrm{E}^{1} 1 / 2$ & $\mathrm{E}^{2} 1 / 2$ \\
\hline $\mathbf{L}^{\mathbf{1}}$ & 0.51 & 0.93 \\
$\mathbf{L}^{\mathbf{2}}$ & 0.51 & 0.92 \\
$\mathbf{1}$ & 0.48 & 0.94 \\
$\mathbf{2}$ & 0.52 & 0.96 \\
$\mathbf{3}$ & 0.51 & 0.97 \\
\hline
\end{tabular}

The electrochemistry of complexes $\mathbf{1 - 3}$ remains similar to that of the free ligands, the coordination of the electron attracting $\mathrm{Ln}(\mathrm{hfac})_{3}$ fragments does not significantly affect the oxidation potentials (Table 2 ). The electrochemical properties attest that the reversibility of the oxidation potentials and the redoxactivity of both ligands ( $\mathbf{L}^{\mathbf{1}}$ and $\mathbf{L}^{\mathbf{2}}$ ) are conserved after complexation.

Photo-physical Properties. The UV-visible absorption properties of $\mathbf{L}^{\mathbf{1}}, \mathbf{L}^{\mathbf{2}}$ and complexes $\mathbf{1}$ and $\mathbf{2}$ have been studied both in solution $\left(\mathrm{CH}_{2} \mathrm{Cl}_{2}\right.$, Figs. 5 and $\left.\mathrm{S10}\right)$ and solid-state $(\mathrm{KBr}$ pellets, Figs. S11-S15). To rationalize the attributions of the experimental absorption bands, TD-DFT calculations were performed on the DFT-optimized geometries (see computational details) of the ligands $\mathbf{L}^{\mathbf{1}}$ and $\mathbf{L}^{\mathbf{2}}$ and the $\mathrm{Y}^{\text {III }}$ analogues of complexes $\mathbf{1}$ and $\mathbf{2}$, following a computational strategy already used successfully on other TTF-based systems. ${ }^{16 \mathrm{~g}, 17 \mathrm{~b}, 37}$
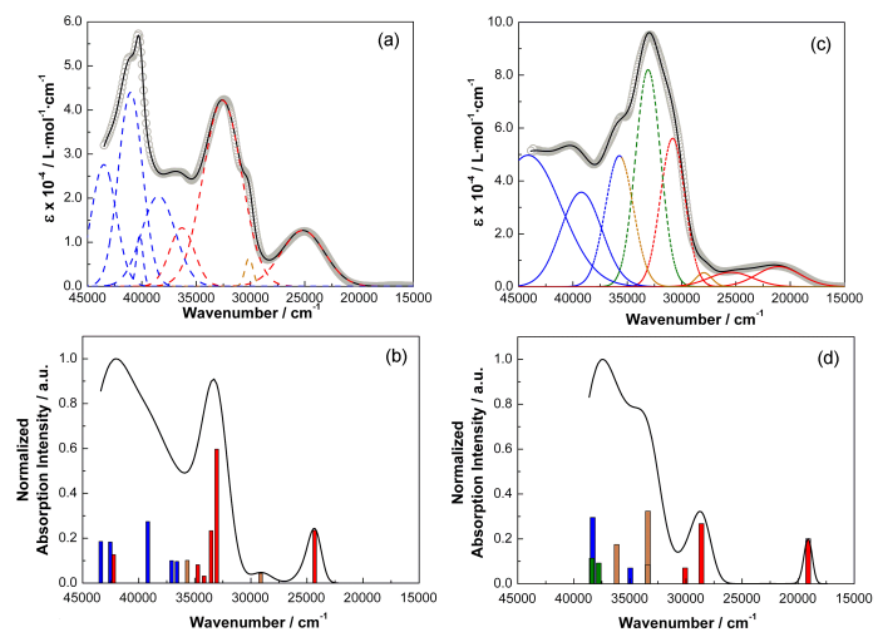

Fig. 5 a) Experimental UV/vis absorption spectrum in solution ( $c=4 \cdot 10^{-5} \mathrm{M}$ ) of $\mathrm{L}^{1}$ in $\mathrm{CH}_{2} \mathrm{Cl}_{2}$ (open grey circles), respective Gaussian decompositions (dashed lines) and best fit (full black line). b) Theoretical absorption spectrum (black line), the bars represent the mean contribution of the absorption spectra that are listed in Table 3. c) Experimental UV/vis absorption spectrum in solution $\left(c=4 \cdot 10^{-5} \mathrm{M}\right.$ ) of 1 in $\mathrm{CH}_{2} \mathrm{Cl}_{2}$ (open grey circles), respective Gaussian decompositions (dashed lines) and best fit (full black line). d) Theoretical absorption spectrum (black line), the bars represent the mean contribution of the absorption spectra that are listed in Table 3.

The molecular orbital diagrams and calculated UV-visible absorption spectra were also determined (Figs. 5-6, S10, S13 and Tables 3 and S3). The experimental absorption curve of $\mathbf{L}^{\mathbf{1}}$ has been decomposed into eight bands (Fig. 5a and Table 3).
The calculated UV-visible absorption spectrum for $\mathbf{L}^{\mathbf{1}}$ reproduces well the experimental curve (Figs. 5a and 5b). The lowest energy band is calculated at $24310 \mathrm{~cm}^{-1}$ (experimental value $25200 \mathrm{~cm}^{-1}$ ) and attributed to a $\pi-\pi^{*}$ HOMO $\rightarrow$ LUMO transition, identified as a TTF to benzoimidazolpyridine (bzip) charge transfer (ILCT) (Fig. 6, Table 3). This result is in agreement with the energy of the ILCT observed for the 4,5bis(propylthio)-tetrathiafulvalenyl]-1 $H$-benzimidazol-2-

yl\}pyridine molecular skeleton $\left(25189 \mathrm{~cm}^{-1}\right)$ showing that the alkylation has no significant influence on the energy of the ILCT. ${ }^{18}$ The next three bands were calculated at 29132, 33294 and $34857 \mathrm{~cm}^{-1}$ (experimental values centred at 30100, 32600 and $36300 \mathrm{~cm}^{-1}$ ) are assigned to intra-TTF transition (ID) (first transition) and ILCT (the next two). The highest energy part of the spectrum is assigned to intra-dpp (IA) transitions.

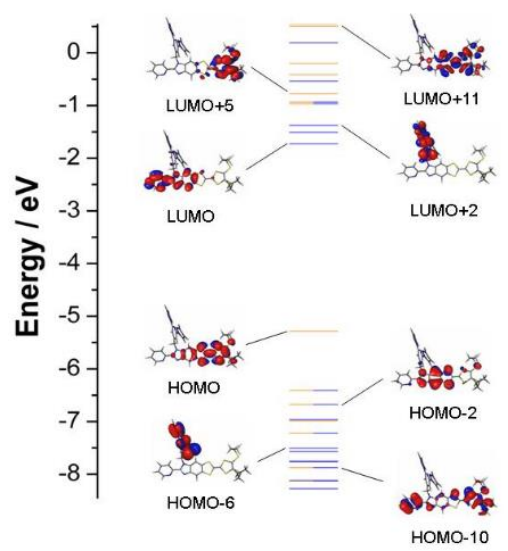

(a)

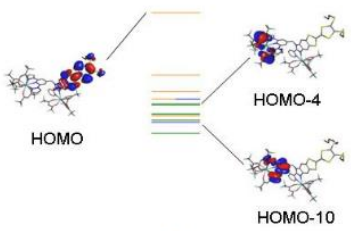

(b)

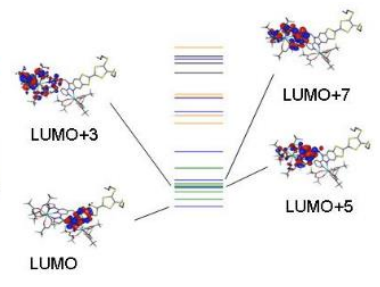

Fig. 6 MO diagram of $\mathbf{L}^{1}$ (left) and complex $\mathbf{1}$ (right). Energy levels of the centered TTF donor, dpp acceptor and $\mathrm{hfac}^{-}$are represented in orange, blue and green, respectively.

The experimental absorption curve of $\mathbf{1}$ was decomposed also into eight bands (Fig. 5c and Table 3). The calculated UV-visible absorption spectrum for 1 reproduces well the experimental curves (Figs. $5 \mathrm{c}$ and $5 \mathrm{~d}$ ). The lowest energy band was calculated at $19113 \mathrm{~cm}^{-1}$ (experimental value at $21000 \mathrm{~cm}^{-1}$ ) and attributed to a $\pi-\pi^{*}$ HOMO $\rightarrow$ LUMO transition (Fig. 6), identified as a TTF to benzoimidazolpyridine (bzip) charge transfer (ILCT). This band is significantly lower (by $\sim 4200 \mathrm{~cm}^{-1}$ ) than the experimental energy for the free ligand $\mathbf{L}^{1}\left(25200 \mathrm{~cm}^{-1}\right)$ due to the electron-withdrawing character of the $\mathrm{Yb}(\mathrm{hfac})_{3}$ moiety, which decreases the electron density of the orbitals centered on both the acceptor and the donor parts of the ligand. Also upon the coordination of the $\mathrm{Yb}(\mathrm{hfac})_{3}$ moiety there is the appearance of a new band centered at $38092 \mathrm{~cm}^{-1}$ (experimental value at $33100 \mathrm{~cm}^{-1}$ ) that is attributed to intrahfac' excitations. The experimental absorption curve of $\mathbf{L}^{\mathbf{2}}$ has been decomposed into eight bands (Fig. S10a and Table S3). The calculated UV-visible absorption spectrum for $\mathbf{L}^{\mathbf{2}}$ reproduces well the experimental curve (Figs. S10a and S10b). The lowest energy band is calculated at $23321 \mathrm{~cm}^{-1}$ (experimental value at $24500 \mathrm{~cm}^{-1}$ ) and attributed to a $\pi-\pi^{*}$ HOMO $\rightarrow$ LUMO transition, identified as a TTF to benzoimidazolpyridine (bzip) charge transfer (ILCT) (Fig. S13, Table S3). 
Table 3. TD-DFT calculated excitation energies and main compositions of the low-lying electronic transitions for $\mathbf{L}^{\mathbf{1}}$ and $\mathbf{1}$. In addition, the charge transfer and the pure intramolecular transitions are reported. ID, IA, $\mathrm{H}$ and L represent the intramolecular TTF (Donor) or intramolecular dpp (Acceptor) transitions, and the HOMO and LUMO, respectively. Therefore, ILCT stands for Intra-Ligand Charge Transfer. The theoretical values are evaluated at the $\mathrm{PCM}\left(\mathrm{CH}_{2} \mathrm{Cl} \mathrm{l}_{2}\right)-\mathrm{PBE} 0 / \mathrm{SVP}$ level of approximation.

\begin{tabular}{|c|c|c|c|c|c|c|}
\hline & $\begin{array}{c}E_{\exp } \\
\left(\mathrm{cm}^{-1}\right)\end{array}$ & $\begin{array}{c}E_{\text {theo }} \\
\left(\mathrm{cm}^{-1}\right)\end{array}$ & Osc. & Type & Assignment & Transition \\
\hline \multirow{17}{*}{$L^{1}$} & 25200 & 24310 & 0.28 & ILCT & $\pi_{\mathrm{TTF}} \rightarrow \pi^{*}$ bzip & $\mathrm{H} \rightarrow \mathrm{L}(82 \%)$ \\
\hline & 30100 & 29132 & 0.05 & ID & $\pi_{\mathrm{TTF}} \rightarrow \pi^{*}{ }_{\mathrm{TTF}}$ & $H \rightarrow L+5(94 \%)$ \\
\hline & \multirow{2}{*}{32600} & 33046 & 0.70 & ILCT & $\pi_{\mathrm{TFF}} \rightarrow \pi_{\text {bzip }}$ & $H \rightarrow L+6(36 \%)$ \\
\hline & & 33542 & 0.27 & ID & $\pi_{\mathrm{TTF}} \rightarrow \pi^{*} \mathrm{TTF}$ & $\mathrm{H} \rightarrow \mathrm{L}+7(31 \%)$ \\
\hline & \multirow{3}{*}{36300} & \multirow{3}{*}{$\begin{array}{l}34732 \\
35670\end{array}$} & \multirow{3}{*}{$\begin{array}{l}0.10 \\
0.12\end{array}$} & \multirow{3}{*}{$\begin{array}{l}\text { ILCT } \\
\text { ID }\end{array}$} & \multirow{3}{*}{$\begin{array}{l}\pi_{\mathrm{TTF}} \rightarrow \pi^{*} \text { bzip } \\
\pi_{\mathrm{TTF}} \rightarrow \pi^{*} \mathrm{TTF}\end{array}$} & $\mathrm{H}-2 \rightarrow \mathrm{L}(74 \%)$ \\
\hline & & & & & & $\mathrm{H}-1 \rightarrow \mathrm{L}+4$ (26\%) \\
\hline & & & & & & $\mathrm{H} \rightarrow \mathrm{L}+7 / 10(23 / 21 \%)$ \\
\hline & \multirow{2}{*}{38500} & 36594 & 0.11 & \multirow{2}{*}{ IA } & \multirow{2}{*}{$\pi_{\text {bzip }} \rightarrow \pi_{\text {dpp }}^{*}$} & $\mathrm{H}-2 \rightarrow \mathrm{L}+1(80 \%)$ \\
\hline & & 37070 & 0.12 & & & $\mathrm{H}-3 \rightarrow \mathrm{L}+1 / 2(14 / 17 \%)$ \\
\hline & 40200 & 39191 & 0.32 & IA & $\pi_{\text {bzip }} \rightarrow \pi^{*}$ dpp & $\mathrm{H}-3 \rightarrow \mathrm{L}+1 / 2(34 / 45 \%)$ \\
\hline & \multirow{5}{*}{41000} & \multirow{5}{*}{$\begin{array}{l}42237 \\
42537\end{array}$} & \multirow{5}{*}{$\begin{array}{l}0.15 \\
0.22\end{array}$} & \multirow{5}{*}{$\begin{array}{c}\text { IA } \\
\text { ILCT }\end{array}$} & \multirow{5}{*}{$\begin{array}{l}\pi_{\text {bzip }} \rightarrow \pi_{\text {dpp }}^{*} \\
\pi_{\mathrm{TTF}} \rightarrow \pi_{\text {bzip }}^{*}\end{array}$} & $\mathrm{H}-13 \rightarrow \mathrm{L}(16 \%)$ \\
\hline & & & & & & $H-7 \rightarrow L+1(44 \%)$ \\
\hline & & & & & & $\mathrm{H}-6 \rightarrow \mathrm{L}(22 \%)$ \\
\hline & & & & & & $\mathrm{H}-2 \rightarrow \mathrm{L}+5(10 \%)$ \\
\hline & & & & & & $H-1 \rightarrow L+6(26 \%)$ \\
\hline & & 43380 & 2ר?ח & IA & & $\mathrm{H}-7 \rightarrow \mathrm{L}+2$ (16\%) \\
\hline & 43500 & 43380 & 0.22 & IA & $\pi \mathrm{dpp} \rightarrow \pi \mathrm{dpp}$ & $\mathrm{H}-6 \rightarrow \mathrm{L} /+2(17 / 25 \%)$ \\
\hline \multirow{10}{*}{1} & 21100 & 19114 & 0.27 & ILCT & $\pi \mathrm{\pi TF} \rightarrow \pi^{*}$ bzip & $\mathrm{H} \rightarrow \mathrm{L}(99 \%)$ \\
\hline & 25400 & 28624 & 0.36 & ILCT & $\pi_{\mathrm{T} \mathrm{FF}} \rightarrow \pi_{\text {bzip }}$ & $\mathrm{H}-1 \rightarrow \mathrm{L}(94 \%)$ \\
\hline & 27900 & 30080 & 0.09 & ILCT & $\pi \pi \mathrm{TTF} \rightarrow \pi_{\text {bzip }}$ & $\mathrm{H}-3 / 2 \rightarrow \mathrm{L}(36 / 58 \%)$ \\
\hline & 30800 & 33399 & 0.43 & ID & $\pi \mathrm{TF} \rightarrow \pi^{*} \mathrm{TTF}$ & $\mathrm{H} \rightarrow \mathrm{L}+14(46 \%)$ \\
\hline & \multirow{3}{*}{33100} & 37787 & 0.12 & \multirow{3}{*}{$\begin{array}{l}\text { Ihfac } \\
\text { IA }\end{array}$} & \multirow{3}{*}{$\begin{array}{l}\pi_{\mathrm{hfac}} \rightarrow \pi_{\mathrm{hfac}}^{*} \\
\pi_{\mathrm{dpp}} \rightarrow \pi_{\mathrm{dpp}}^{*}\end{array}$} & \multirow{3}{*}{$\begin{array}{c}H-11 \rightarrow L+1 / 2(29 / 54 \%) \\
H-10 \rightarrow L+7(39 \%)\end{array}$} \\
\hline & & 38316 & 0.39 & & & \\
\hline & & 38398 & 0.15 & & & \\
\hline & 35700 & 34966 & 0.09 & IA & $\pi_{\mathrm{dpp}} \rightarrow \pi_{\mathrm{dpp}}$ & $\mathrm{H}-10 \rightarrow \mathrm{L}+3(23 \%)$ \\
\hline & 39200 & 36182 & 0.23 & ID & $\pi_{\mathrm{TTF}} \rightarrow \pi^{*} \mathrm{TTF}$ & $\mathrm{H}-1 \rightarrow \mathrm{L}+10(30 \%)$ \\
\hline & 44100 & / & / & l & / & / \\
\hline
\end{tabular}

The next two bands were calculated at 28703 and $32112 \mathrm{~cm}^{-1}$ (experimental values centred at 27500 and $30400 \mathrm{~cm}^{-1}$ ) and are attributed to an intra-TTF transition (ID) and another ILCT. The rest of the spectrum is a mix of intra-Mebpy (IA) and intra-TTF (ID) transitions. The experimental absorption curve of $\mathbf{2}$ was decomposed into nine bands (Fig. S10c and Table S3). The calculated UV-visible absorption spectrum for $\mathbf{2}$ reproduces well the experimental curves (Figs. S10c and S10d). The lowest energy band was calculated at $19304 \mathrm{~cm}^{-1}$ (experimental value at $21600 \mathrm{~cm}^{-1}$ ) and attributed to a $\pi-\pi^{*}$ HOMO $\rightarrow$ LUMO transition, identified as a TTF to benzoimidazolpyridine (bzip) charge transfer (ILCT) (Fig. S13). This band is significantly lower (by $\sim 2900 \mathrm{~cm}^{-1}$ ) than the experimental energy for the free ligand $\mathrm{L}^{2}\left(24500 \mathrm{~cm}^{-1}\right)$ due to the electron-withdrawing character of the $\mathrm{Yb}(\mathrm{hfac})_{3}$ moiety, which decreases the electron density of the orbitals centered on both the acceptor and the donor parts of the ligand. Also upon the coordination of the $\mathrm{Yb}(\mathrm{hfac})_{3}$ moiety there is the appearance of a new band centered at $38196 \mathrm{~cm}^{-1}$ (experimental value at $33700 \mathrm{~cm}^{-1}$ ). This band is attributed to intra-hfac- excitations.

Metal-centered luminescence. The emission properties of complexes $\mathbf{1}$ and $\mathbf{2}$ were studied at room temperature and at 77 $\mathrm{K}$ in solid state (Figs. 7 and 8). Excitation of the samples at 20000 $\mathrm{cm}^{-1}$ induces the luminescence of the $\mathrm{Yb}^{\text {III }}$ ions, assigned to the ${ }^{2} \mathrm{~F}_{5 / 2} \rightarrow{ }^{2} \mathrm{~F}_{7 / 2}$ transition. Ten emission maxima and shoulders are clearly identified at the following energies in the spectrum of 2: $10206 \mathrm{~cm}^{-1}, 9961 \mathrm{~cm}^{-1}, 9927 \mathrm{~cm}^{-1}, 9871 \mathrm{~cm}^{-1}, 9840 \mathrm{~cm}^{-1}, 9797$ $\mathrm{cm}^{-1}, 9756 \mathrm{~cm}^{-1}, 9709 \mathrm{~cm}^{-1}, 9696 \mathrm{~cm}^{-1}$ and $9624 \mathrm{~cm}^{-1}$ (Figure 8). This number of contributions is higher than the degeneracy of the ${ }^{2} \mathrm{~F}_{7 / 2}$ ground state (Kramer's doublets), which has a maximum of four contributions. These additional emission contributions cannot only be explained by the presence of two distinct $\mathrm{Yb}^{\prime \prime \prime}$ ions in the complex. Indeed although tiny structural 
differences are present, both $\mathrm{Yb}^{\prime \prime \prime}$ emitters present very similar polyhedron symmetry $\left(D_{4 d}\right)$ and therefore the same crystal field splitting in the luminescence spectra is expected. The presence of additional signals, that are frequently observed, could thus be attributed to additional transitions coming from the second and/or third $\mathrm{M}_{\text {J }}$ states of the ${ }^{2} \mathrm{~F}_{5 / 2}$ multiplet by analogy with some of our previous studies ${ }^{37}$ and the one by Auzel et $a .^{39}$ or to vibrational contributions.
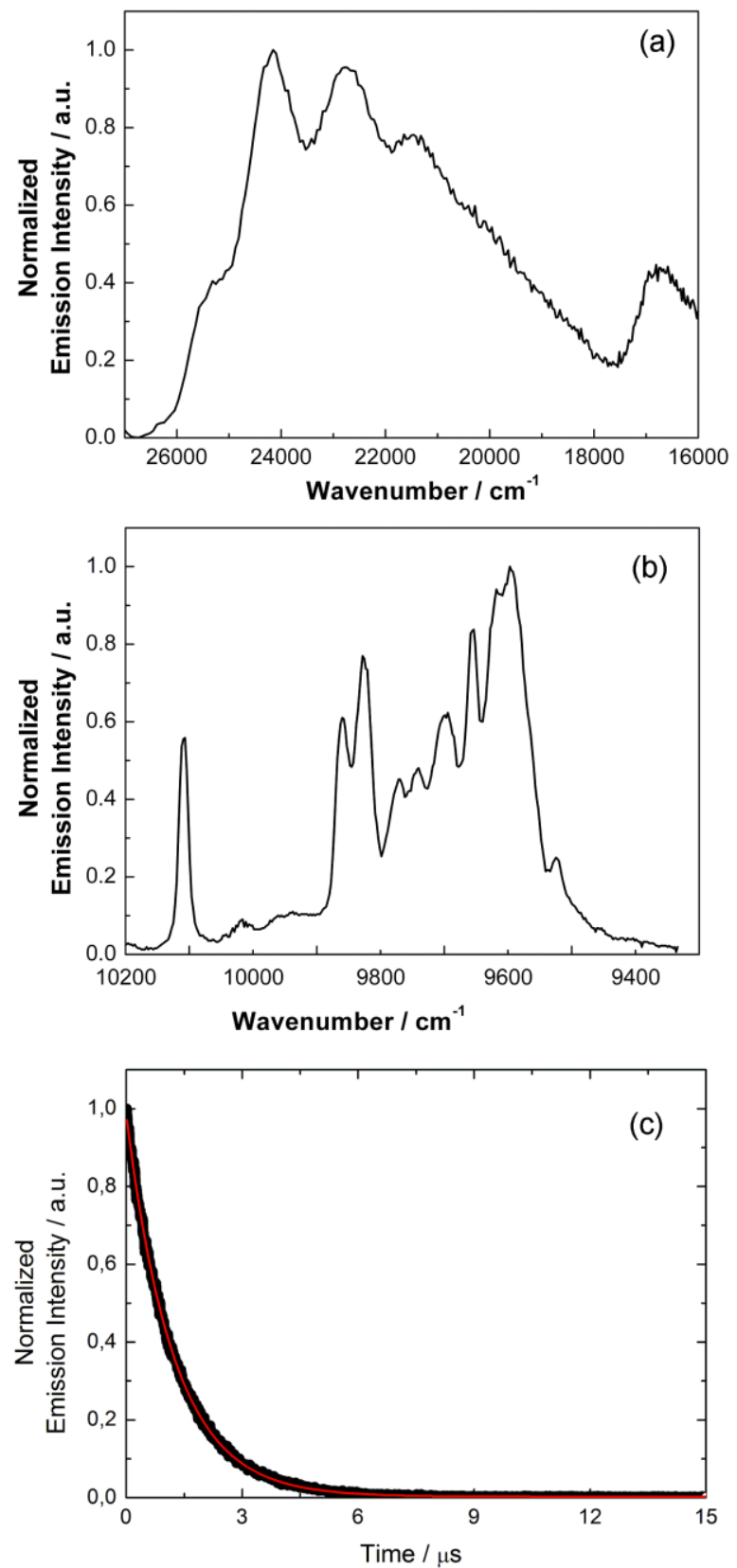

Fig. 7 (a) Visible $\left(\lambda_{\text {ex }}=28570 \mathrm{~cm}^{-1}(350 \mathrm{~nm})\right)$ and (b) NIR $\left(\lambda_{\text {ex }}=20000 \mathrm{~cm}^{-1}(500 \mathrm{~nm})\right.$ luminescence spectra of $\mathbf{2}$ in the solid state at $77 \mathrm{~K}$, (c) Decay kinetics of ${ }^{2} \mathrm{~F}_{5 / 2}$ recorded at $10000 \mathrm{~cm}^{-1}(1000 \mathrm{~nm})$ in solid state at room temperature under $22222 \mathrm{~cm}^{-1}(450 \mathrm{~nm})$ excitation for $\mathbf{2}$. The red line represents the monoexponential fit.

On the other hand, the dissymmetrical bimetallic complex 1 exhibits eleven emission maxima and shoulders at the following energies: $10206 \mathrm{~cm}^{-1}, 10172 \mathrm{~cm}^{-1}, 10115 \mathrm{~cm}^{-1}, 10042 \mathrm{~cm}^{-1}, 9966$ $\mathrm{cm}^{-1}, 9923 \mathrm{~cm}^{-1}, 9871 \mathrm{~cm}^{-1}, 9836 \mathrm{~cm}^{-1}, 9754 \mathrm{~cm}^{-1}, 9685 \mathrm{~cm}^{-1}$, and
$9622 \mathrm{~cm}^{-1}$. Once again, the number of contributions is higher than eight, a value expected for two emitting $\mathrm{Yb}^{\prime \prime \prime}$ ions in two different coordination environments, i.e. two different coordination polyhedra with different symmetries $\left(\mathrm{Yb} 1-\mathrm{N}_{2} \mathrm{O}_{6}\right.$ in $\mathrm{D}_{4 \mathrm{~d}}$ and $\mathrm{Yb} 2-\mathrm{N}_{3} \mathrm{O}_{6}$ in $\mathrm{D}_{3 \mathrm{~h}}$ ). Then the additional emissive bands could be also attributed to the participation of excited $M_{\mathrm{J}}$ states of the ${ }^{2} \mathrm{~F}_{5 / 2}$ multiplet state as well as vibrational contributions.
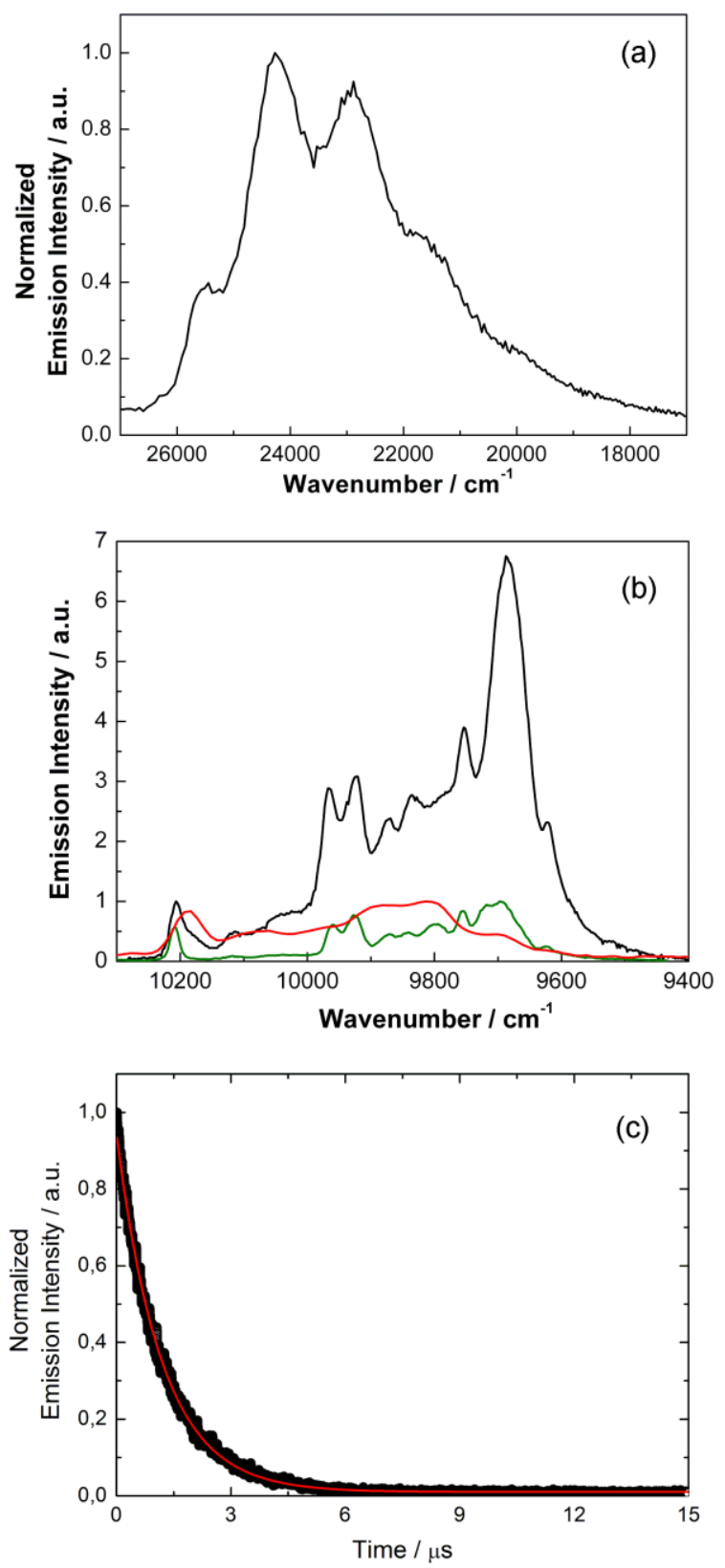

Fig. 8 Visible $\left(\lambda_{\text {ex }}=28570 \mathrm{~cm}^{-1}(350 \mathrm{~nm})\right)$ (a) and NIR $\left(\lambda_{\text {ex }}=20000 \mathrm{~cm}^{-1}(500 \mathrm{~nm})\right)$, (b) luminescence spectra of $\mathbf{1}$ (black line) in the solid state at 77K. For comparison are superimposed the spectra of $\left[\mathrm{Yb}_{2}(\mathrm{hfac})_{6}\left(\mathrm{~L}^{3}\right)\right]^{38}$ (red line) and $\mathbf{2}$ (green line) recorded in the same conditions, (c) Decay kinetics of ${ }^{2} \mathrm{~F}_{5 / 2}$ recorded at $10000 \mathrm{~cm}^{-1}(1000 \mathrm{~nm})$ in solid state at room temperature under $22222 \mathrm{~cm}^{-1}(450 \mathrm{~nm})$ excitation for $\mathbf{1}$. The red line represents the monoexponential fit.

To visualize the contributions of the different $Y b^{\prime \prime \prime}$ ions, we compared the first emission band of the spectra of 1 (black line in Fig. 8) with an analogous complex of formula $\left[\mathrm{Yb}_{2}(\mathrm{hfac})_{6}\left(\mathrm{~L}^{3}\right)\right] \cdot \mathrm{C}_{6} \mathrm{H}_{14}$ (where $\mathbf{L}^{3}=$ bis(2,6-di(pyrazol-1-yl)-4- 
methylthiolpyridine)-4', $5^{\prime}$-ethylenedithiotetrathiafulvene) that has two $\mathrm{Yb}^{111}$ ions in a $\mathrm{N}_{3} \mathrm{O}_{6}$ environment ${ }^{40}$ (red line in Fig. 8) and with complex 2 (green line in Fig. 8). The first emission band is at $10206 \mathrm{~cm}^{-1}$ at the same position than in complex $\mathbf{2}$ and has a shoulder at $10172 \mathrm{~cm}^{-1}$ due to the contribution of the $\mathrm{Yb}^{\prime \prime \prime}$ ions in a $\mathrm{N}_{3} \mathrm{O}_{6}$ environment. Qualitatively, contributions of the two types of coordination environment can be found for $\mathbf{1}$ but the resolution of the spectra is not good enough to draw any definitive conclusions. It was recently demonstrated that the presence of a low-energy ILCT transition can suggest a sensitization occurring directly via the transfer of energy from the charge transfer state. ${ }^{12,15 c, d, 41}$ The presence of the phosphorescence signal at $77 \mathrm{~K}$ (Figs. 7a, 8a) suggests that the ${ }^{3} \pi \pi^{*}$ state should be also involved in the sensitization mechanism. ${ }^{42}$ In the present case, it is complicated to discriminate between the possible sensitization processes and both energy transfers from singlet and triplet excited states may simultaneously occur. As already observed for similar TTF-based ligands, for example the 4,5-bis(propylthio)-tetrathiafulvalene2-(2-pyridyl)benzimidazole-methyl-2-pyridine ligand, ${ }^{42}$ and due to the presence of the $\mathrm{Yb}^{\prime \prime \prime}$ ion an additional sensitization process involving a stepwise photo-induced electron transfer can be considered.

For both complexes, the luminescence decay was best fitted by a single exponential function of time synonymous with a ${ }^{2} \mathrm{~F}_{5 / 2}$ state lifetime of $12.2 \mu$ s for complex 2 (Fig. 7c) and $11.9 \mu$ s for complex 1 (Fig. 8c). The presence of two different emitting centres in $\mathbf{1}$ does not give two significantly different emission lifetimes. Such lifetimes are in the range of the standard $\left\{\mathrm{Yb}(\mathrm{hfac})_{3}\right.$ (diimine) $\}$ luminophores ${ }^{43}$ as well as with our previously reported $\left[\mathrm{Yb}(\mathrm{hfac})_{3}\left(\mathrm{~L}^{4}\right)\right]$ complex (where $\mathrm{L}^{4}=4,5$ bis(propylthio)-tetrathiafulvalene- 2-(2-pyridyl)benzimidazolemethyl-2-pyridine). ${ }^{42}$

\section{Magnetic properties}

Static magnetic measurements were performed on the four compounds. The temperature dependences of $\chi_{M} T$ for powdered samples of 1-3 are represented in Fig. 9.

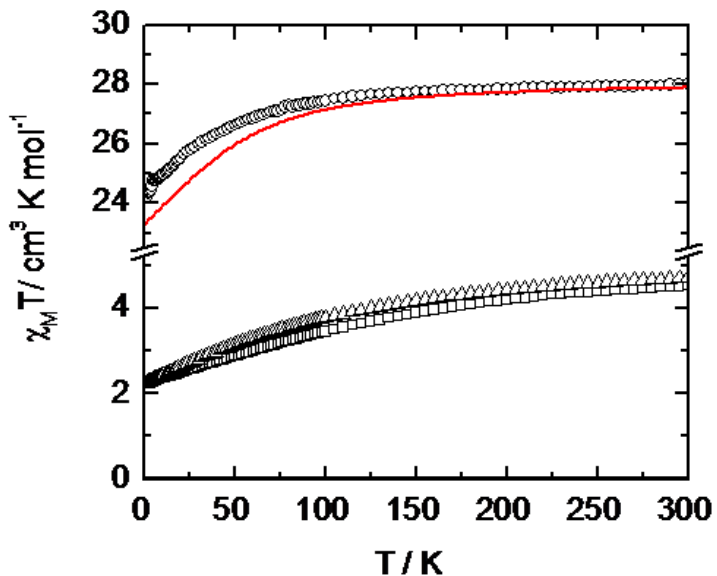

Fig. 9 . Thermal variation of $\chi_{M} T$ for compounds $\mathbf{1}$ (triangles), $\mathbf{2}$ (squares) and $\mathbf{3}$ (circles) with simulated curve (red line) for $\mathbf{3}$.
The room temperature values are $4.72 \mathrm{~cm}^{3} \cdot \mathrm{K} \cdot \mathrm{mol}^{-1}, 4.53$ $\mathrm{cm}^{3} \cdot \mathrm{K} \cdot \mathrm{mol}^{-1}$, and $28.00 \mathrm{~cm}^{3} \cdot \mathrm{K} \cdot \mathrm{mol}^{-1}$ for $1-3$, respectively. On cooling, $\chi_{M} T$ decreases monotonically down to $2.25 \mathrm{~cm}^{3} \cdot \mathrm{K} \cdot \mathrm{mol}^{-}$ $1,2.31 \mathrm{~cm}^{3} \cdot \mathrm{K} \cdot \mathrm{mol}^{-1}, 24.18 \mathrm{~cm}^{3} \cdot \mathrm{K} \cdot \mathrm{mol}^{-1}$ for $1-3$, respectively. The experimental room temperature values of $\chi_{M} T$ are in agreement with the expected values of $5.14 \mathrm{~cm}^{3} \cdot \mathrm{K} \cdot \mathrm{mol}^{-1}$ and $28.34 \mathrm{~cm}^{3} \cdot \mathrm{K} \cdot \mathrm{mol}^{-1}$ for two magnetically isolated $\mathrm{Yb}^{\prime \prime \prime}$ and Dy"I, respectively. ${ }^{44}$ For compounds $\mathbf{1 - 3}$, classical behaviour in the field range 0-50 kOe is observed from the first magnetization curves measured at $2 \mathrm{~K}$ for magnetically isolated lanthanides (Fig. S16).

Dynamic Measurements. For the $\mathrm{Yb}^{\prime \prime \prime}$ derivatives $\mathbf{1}$ and 2, no out-of-phase component of the magnetic susceptibility $\left(\chi_{M}{ }^{\prime \prime}\right)$ was observed while an immobilized powder of $\mathbf{3}$ shows frequency dependence in zero external dc field but with a maximum of the $\chi_{\mathrm{M}}$ " vs. $v$ curve ( $v$ the frequency of the ac oscillating field) that falls at the limit of the available frequencies (Fig. 10a). The Dy"lI ions lie in almost the same environment $\mathrm{N}_{2} \mathrm{O}_{6}-\mathrm{D}_{4 d}$ and should therefore behave similarly. This is indeed what is observed in the extended Debye $\mathrm{e}^{45}$ analysis of the $2 \mathrm{~K}$ data in zero field with only one relaxing centre that shows that the relaxation process concerns more than $70 \%$ of the magnetic moment (Fig. S17). The application of a moderate external dc field induces the appearance of a second relaxation process at low frequency which grows at the expense of the fast relaxation process (Fig. 10a). Only at fields higher than 800 Oe one relaxation is visible. The optimum field, the field for which relaxation is slowest, is estimated at 800 Oe (Fig. 10a).
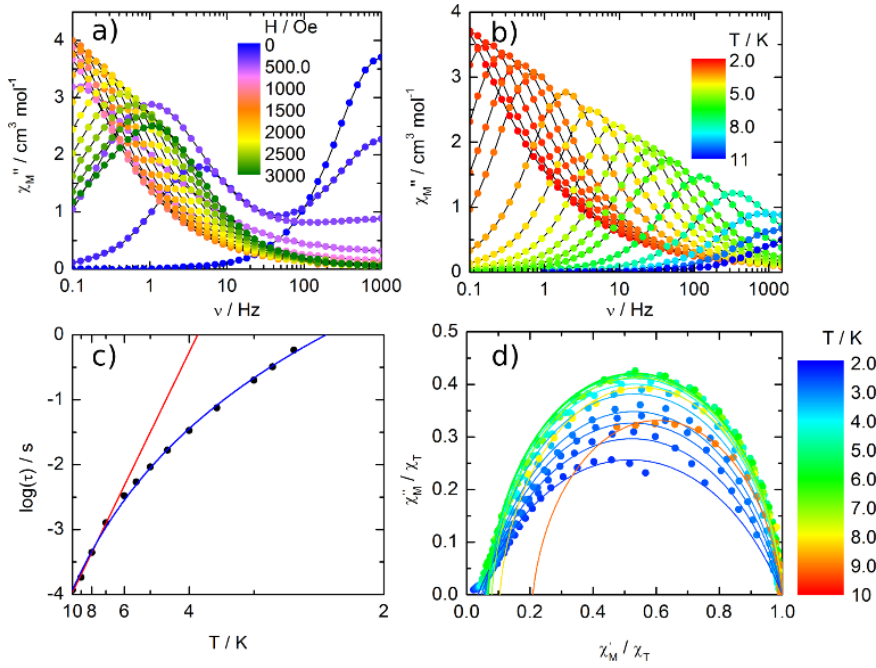

Fig. 10 (a) Scan field of the frequency dependence of $\chi_{M}{ }^{\prime \prime}$ of $\mathbf{3}$ at $2 \mathrm{~K}$, (b) Frequency dependence of $\chi_{\mathrm{M}}$ " between 2 and $10 \mathrm{~K}$, (c) temperature variation of the relaxation time measured in an external field of 800 Oe with the best fitted curve (red line) in the temperature range of $2.5-10 \mathrm{~K}$, and (d) normalized Cole-Cole plots at several temperatures between 2 and $10 \mathrm{~K}$.

In such applied field, the out-of-phase component of $\chi_{M}$ was observed in the temperature range of 2-11 K (Fig. 10b). The frequency dependence of the ac susceptibility can be analysed in the framework of the extended Debye model both for field and temperature variations. Both Dy ${ }^{\prime \prime \prime}$ ion sites are treated 
identically and relax at the same rate: only one maximum is observed on the $\chi_{M}{ }^{\prime \prime}$ vs. $v$ curves at any temperature. The temperature dependence of the relaxation time at 800 Oe is extracted from the extended Debye model between 2.0 and $10.0 \mathrm{~K}$ (Table S4). The relaxation time follows the Arrhenius law $\tau=\tau_{0} \exp (\Delta / \mathrm{kT})$ only above $6 \mathrm{~K}$ with $\tau_{0}=3.7(1.3) \times 10^{-7} \mathrm{~s}$ and $\Delta=$ $39.6(2) \mathrm{cm}^{-1}$ (Figure $11 \mathrm{c}$ ) while the full curve is easily reproduced with a Raman only process $\tau=C \times T^{n}$ with $C=4.8(6) \times 10^{-3}$ and $n=$ $6.26(7)$. The value of $\mathrm{n}$ is close to 7 expected for Kramers ions ${ }^{46}$ which tends to prove that the relaxation does not occur through first excited state. The Cole-Cole ${ }^{46 \mathrm{~b}}$ plots normalized to their isothermal value are represented in Fig. 10d. Only the plots with maximum on $\chi_{M}{ }^{\prime \prime}$ vs. $\chi_{M}{ }^{\prime}$ are shown. Clearly, the curves do not collapse into a single master one.

Relaxation times on the order of a second remain too fast to observe the opening of the hysteresis loop at $2 \mathrm{~K}$ while at 0.47 $\mathrm{K}$ the hysteresis loop slightly opens (Fig. 11).

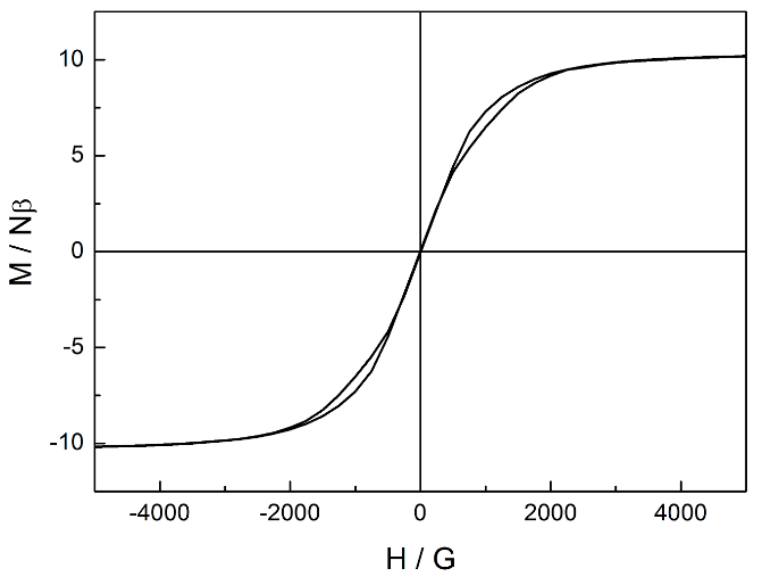

Fig. 11 Magnetic hysteresis loop of $\mathbf{3}$ measured at $0.47 \mathrm{~K}$.

Observation of remnant magnetization (residual magnetization in the absence of an external field) is problematic in the case of mononuclear complexes of Dy'll. The typical butterfly-shaped hysteresis loop observed in $\mathbf{3}$, is a consequence of the hyperfine coupling and the internal field created in condensed phases by neighbouring molecules.

$\boldsymbol{A} \boldsymbol{b}$ initio calculations. SA-CASSCF/RASSI-SO calculations were performed on two separate Dy III monomeric fragments of $\mathbf{3}$ to rationalize the observed magnetic properties (see computational details). Energy spectra and $g$ tensors for the eight Kramer's doublets of the ground ${ }^{6} \mathrm{H}_{15 / 2}$ multiplet of the two Dy'II ions are given in Figure S18 and Table S5. The energy splitting of the ${ }^{6} \mathrm{H}_{15 / 2}$ multiplet is almost identical for the two Dy"l' ions leading to similar magnetic contributions of each metallic centre in the thermal dependence of the $\chi_{M} T^{\top}$ product. The calculated $\chi_{M} T$ vs T (Fig. 11) and M vs H (Fig. S16) curves fairly well reproduced the experimental curves. Calculations confirm the axial character of the magnetic anisotropy tensor of the ground Kramer's doublet with large $g_{z}$ values of 19.24 for Dy1 and 19.34 for Dy2 and almost negligible $g_{x}$ and $g_{y}$ values (Table S5). It clearly appears that the $g_{z}$ value for Dy1 and Dy2 is close to the expected $g_{z}=20$ for a pure $M_{\jmath}= \pm 15 / 2$ ground state. ${ }^{47}$ The calculated ground-state easy axis (Fig. 12) for each Dy"II ion is oriented perpendicular to the plane formed by the \{tetrathiafulvalenyl-1H-benzimidazol-2-yl\}pyridine and bipyridine moieties as expected for an oblate ion. ${ }^{48,16 \mathrm{~g}}$ Moreover, magnetic relaxation pathways can be interpreted on the basis of magnetic transition moments (Fig. 13). It confirms the similarity in the dynamic magnetic properties for both Dy ${ }^{\prime \prime \prime}$ ions. In both cases, no direct transition is expected whereas relaxation mechanisms involving the first and second $M_{J}$ states are highly probable.

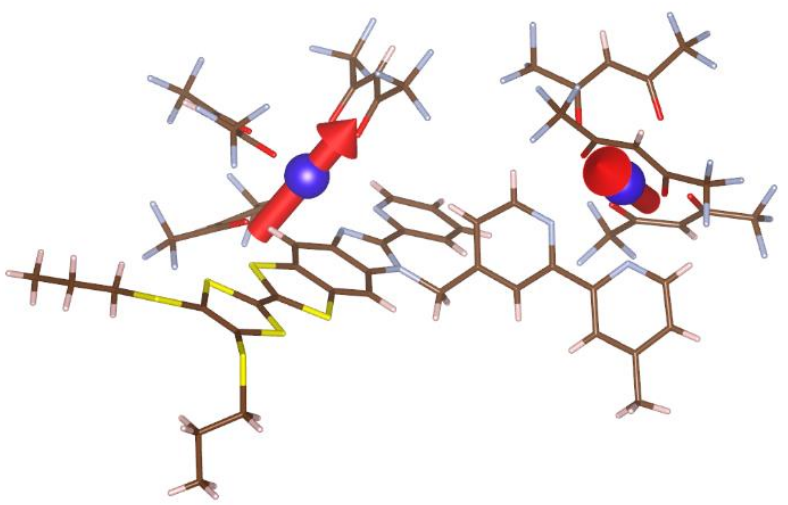

Fig. 12 Representation of complex $\mathbf{3}$ with theoretical orientations of the easy magnetic axis of the two Dy"l' centres.
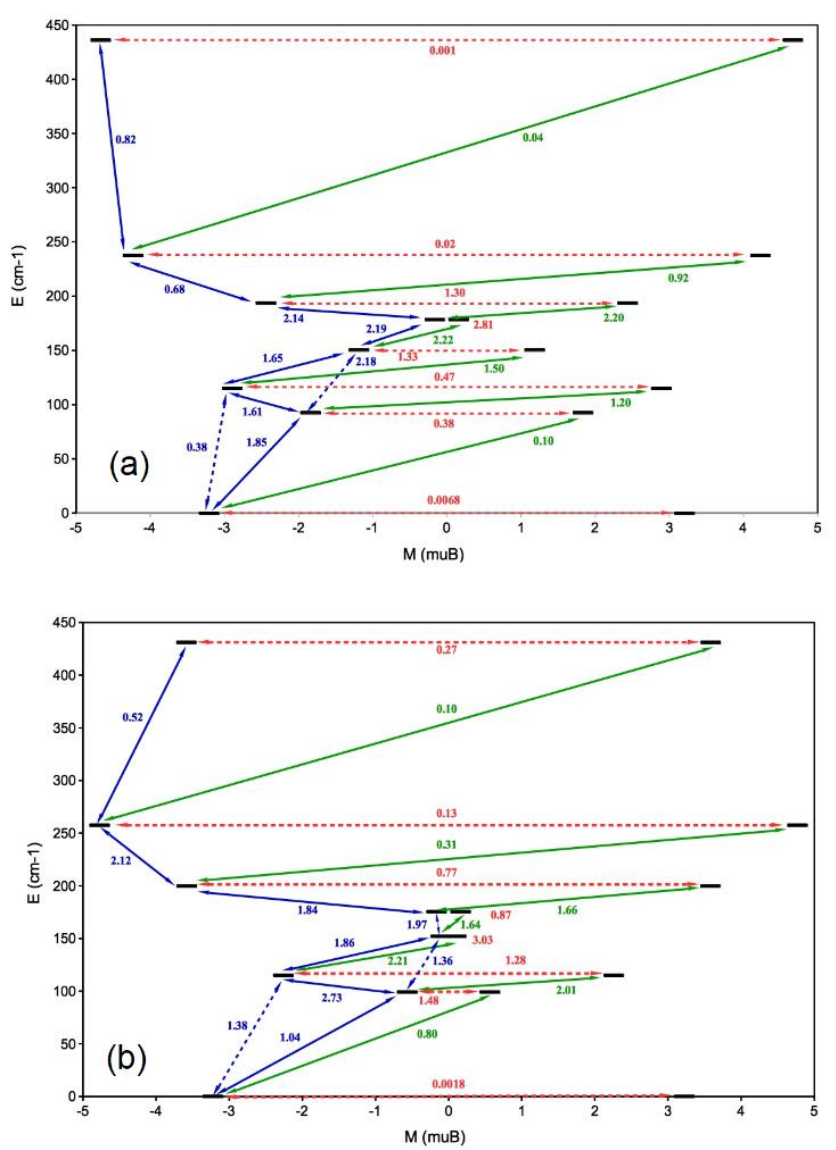

Fig. 13 Computed magnetization blocking barriers in complex 3 for Dy1 (a) and Dy2 (b) ions. Numbers provided on each arrow are the mean absolute values for the corresponding matrix elements of the magnetic transition dipole moment. 
Slightly different relaxation pathways are calculated for the two metal sites, however these variations are not enough to experimentally discriminate the two Dy"l' ions. The calculations indicate a difference between the $\Delta$ and the expected barrier, being the latter almost the double of the former: $\sim 90 \mathrm{~cm}^{-1} \mathrm{vs}$ $\sim 40 \mathrm{~cm}^{-1}$. However, such discrepancy is pretty common in literature ${ }^{49}$ and probably due the contribution of coupling of spin-phonon degrees of freedom in the SMM relaxation mechanisms. The latter are not accounted in the $a b$ initio model. The general importance of such contributions was recently evidenced in the spin-phonon bottleneck mechanism ${ }^{50}$ and in the strong dependence both in sign and magnitude of anisotropic exchange on single vibrational mode ${ }^{51}$.

\section{Conclusions}

The present work describes the crystal structure of two TTFbased ligands involving either 2,6-di(pyrazol-1-yl)-4pyridine ( $\left.\mathbf{L}^{\mathbf{1}}\right)$ or $4,4^{\prime}$-dimethyl-2,2'-bipyridine $\left(\mathbf{L}^{2}\right)$ as second coordinating fragment while the first one is insured by the fused benzimidazol-2-yl-pyridine. Three dinuclear coordination complexes of formulae $\left[\mathrm{Yb}_{2}(\mathrm{hfac})_{6}\left(\mathrm{~L}^{1}\right)\right] \cdot 2\left(\mathrm{CH}_{2} \mathrm{Cl}_{2}\right) \cdot \mathrm{C}_{6} \mathrm{H}_{14}(\mathbf{1})$ and $\left[\mathrm{Ln}_{2}(\mathrm{hfac})_{6}\left(\mathrm{~L}^{2}\right)\right] \cdot \mathrm{CH}_{2} \mathrm{Cl}_{2}(\mathrm{Ln}=\mathrm{Yb}(\mathbf{2})$ and Dy (3)) have been synthesized. Their $\mathrm{X}$-ray structures reveal that both coordination sites can be occupied in the case of Dy $\mathrm{y}^{\mathrm{II}}$ and $\mathrm{Yb}^{\mathrm{II}}$ ions. The lanthanide ions in eight-coordination environment adopt square antiprism polyhedra $\left(D_{4 d}\right.$ symmetry) while the ones in nine-coordination sphere adopt spherical tricapped trigonal prism $\left(D_{3 h}\right)$.

The UV-visible absorption properties of the ligands and relative complexes have been determined and rationalized by TD-DFT calculations. The lowest-energy absorption bands have been attributed to HOMO $\rightarrow$ LUMO ILCT bands and used to sensitize

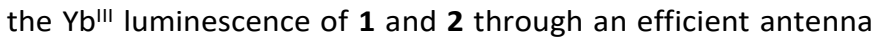

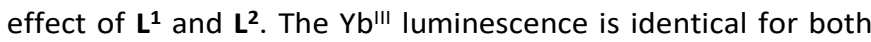
metal centres in $\mathbf{2}$ since they adopt very similar environment and coordination polyhedra symmetry while two distinct emission contributions can be quantitatively distinguished for 1. This is in agreement with the two magnetic behaviours observed in the Dy III analogue of $\mathbf{1}$ which has been previously studied by some of us. ${ }^{18}$

On a magnetic point of view, compound 3 behaves as a SMM with an opening of the hysteresis loop detected at low temperature. The two Dy'll centres have very similar dynamic characteristics. $A b$ initio calculations rationalized the uniaxiality of the magnetic anisotropy for both Dy1 and Dy2 ions and the orientations of their anisotropy axis were determined.

In future work, the possibility to selectively coordinate the different chelating coordination sites will be explored in order to open the route to the design of large variety of heterobimetallic pure-lanthanide and $3 d-4 f$ complexes.

\section{Acknowledgements}

This work was supported by Région Bretagne, Rennes Métropole, CNRS, Université de Rennes 1 and FEDER. G.F.G gratefully acknowledges the European Commission through the ERC-AdG 267746 MolNanoMas (project n. 267746) and the ANR (ANR-13-BS07-0022-01) for financial support. B.L.G. and G.F.G. thank the French GENCI/IDRIS-CINES centr for highperformance computing resources.

\section{Notes and references}

1 D. N. Woodruff, R. E. P. Winpenny and R. A. Layfield, Chem. Rev., 2013, 113, 5110-5148.

2 (a) D. Gatteschi, R. Sessoli and J. Villain, Molecular Nanomagnets; Oxford University Press: New York, 2006; (b) L. Bogani and W. Wernsdorfer, Nat. Mater., 2008, 7, 179-186; (c) M. Mannini, F. Pineider, P. Sainctavit, C. Danieli, E. Otero, C. Sciancalepore, A.-M. Talarico, M.-A. Arrio, A. Cornia, D. Gatteschi and R. Sessoli, Nat. Mater., 2009, 8, 194-197; (d) M. N. Leuenberger and D. Loss, Nature, 2001, 410, 789-793; (e) J. Lehmann, A. Gaita-Arino, E. Coronado and D. Loss, Nat. Nanotechnol., 2007, 2, 312-317; (f) M. Ganzhorn, S. Klyatskaya, M. Ruben and W. Wernsdorfer, Nat. Nanotechnol. 2013, 8, 165-169.

3 (a) P.-E. Car, M. Perfetti, M. Mannini, A. Favre, A. Caneschi, R. Sessoli, Chem. Commun., 2011, 47, 3751-3753; (b) G. Cucinotta, M. Perfetti, J. Luzon, M. Etienne, P.-E. Car, A. Caneschi, G. Calvez, K. Bernot and R. Sessoli, Angew. Chem., Int. Ed. 2012, 51, 1606-1610; (c) M.-E. Boulon, G. Cucinotta, J. Luzon, C. Dedl'Innocenti, M. Perfetti, K. Bernot, G. Calvez, A. Caneschi and R. Sessoli, Angew. Chem., Int. Ed., 2013, 52, 350354.

4 (a) S.-D. Jiang, B.-W. Wang, G. Su, Z.-M. Wang and S. Gao, Angew. Chem., Int. Ed., 2010, 49, 7448-7451; (b) R. A. Layfield, J. J. W. Mcdouall, S. A. Sulway, F. Tuna, D. Collison and R. E. P. Winpenny, Chem.-Eur. J., 2010, 16, 4442-4446; (c) S.-D. Jiang, S.-S. Liu, L.-N. Zhou, B.-W. Wang, Z.-M. Wang and S. Gao, Inorg. Chem., 2012, 51, 3079-3087; (d) M. Jeletic, P.-H. Lin, J. J. Le Roy, I. Korobkov, S. I. Gorelsky and M. Murugesu, J. Am. Chem. Soc., 2011, 133, 19286-19289; (e) S. Demir, J. M. Zadrozny and J. R. Long, Chem.-Eur. J., 2014, 20, 9524-9529; (f) J. J. Le Roy, M. Jeletic, S. I. Gorelsky, I. Korobkov, L. Ungur, L. F. Chibotaru and M. Murugesu, J. Am. Chem. Soc., 2013, 135, 3502-3510.

5 (a) N. Ishikawa, M. Sugita, T. Ishikawa, S. Koshihara and Y. Kaizu, J. Am. Chem. Soc., 2003, 125, 8694-8695; (b) K. Wang, S. Zeng, H. Wang, J. Doub and J. Jiang, Inorg. Chem. Front. 2014, 1, 167-171.

6 J. Jung, F. Le Natur, O. Cador, F. Pointillart, G. Calvez, C. Daiguebonne, O. Guillou, T. Guizouarn, B. Le Guennic and K. Bernot, Chem. Commun., 2014, 50, 13346-13348.

7 K. Kuriki, Y. Koike, Y. Okamoto, Chem. Rev., 2002, 102, 23472356.

8 E. G. Moore, A. P. S. Samuel and K. N. Raymond, Acc. Chem. Res., 2009, 42, 542-552 and references therein.

9 (a) J.-C. G. Bünzli, Chem. Rev., 2010, 110, 2729-2755; (b) R. M. Duke, E. B. Veale, F. M. Pfeffer, P. E. Kruger and T. Gunnlaugsson, Chem. Soc. Rev., 2010, 39, 3936-3953.

10 (a) A. Beeby, S. W. Botchway, I. M. Clarkson, S. Faulkner, A. M. Parker, D. Parker and J. A. G. Williams, J. Photochem. Photobiol., B, 2000, 57, 83-89; (b) A. Grichine, A. Haefele, S. Pascal, A. Duperray, R. Michel, C. Andraud, O. Maury, Chem. Science, 2014, 5, 3475-3485.

11 J. H. van Vleck, J. Phys. Chem., 1937, 41, 67-80.

12 A. D'Aléo, F. Pointillart, L. Ouahab, C. Andraud and O. Maury, Coord. Chem. Rev. 2012, 256, 1604-1620.

13 F. Pointillart, B. Le Guennic, O. Cador, O. Maury and L. Ouahab, Acc. Chem. Res., 2015, 48, 2834-2842. 
14 (a) G. Cucinotta, M. Perfetti, J. Luzon, M. Etienne, P. E. Car, A Caneschi, G. Calvez, K. Bernot and R. Sessoli, Angew. Chem. Int. Ed. 2012, 51, 1606-1610; (b) J. Long, R. Vallat, R. A. S. Ferreira, L. D. Carlos, F. A. A. Paz, Y. Guari and J. Larionova, Chem. Commun., 2012, 48, 9974-9976; (c) K. Yamashita, R. Miyazaki, Y. Kataoka, T. Nakanishi, Y. Hasegawa, M. Nakano, T. Yamamura and T. Kajiwara, Dalton Trans., 2013, 42, 19871990; (d) K. Ehama, Y. Ohmichi, S. Sakamoto, T. Fujinami, N. Matsumoto, N. Mochida, T. Ishida, Y. Sunatsuki, M. Tsuchimoto and N. Re, Inorg. Chem. 2013, 52, 12828-12841; (e) M. Ren, S.-S. Bao, R. A. S. Ferreira, L.-M. Zheng and L. D. Carlos, Chem. Commun., 2014, 50, 7621-7624; (f) X. Yi, K. Bernot, V. Le Corre, G. Calvez, F. Pointillart, O. Cador, B. Le Guennic, J. Jung, O. Maury, V. Placide, Y. Guyot, T. Roisnel, C. Daiguebonne and O. Guillou, Chem. Eur. J., 2014, 20, 15691576.

15 (a) S. Faulkner, B. P. Burton-Pye, T. Khan, L. R. Martin, S. D. Wray and P. J. Skabara, Chem. Commun., 2002, 1668-1669; (b) S. J. A. Pope, B. P. Burton-Pye, R. Berridge, T. Khan, P. Skabara and S. Faulkner, Dalton Trans., 2006, 2907-2912; (c) F Pointillart, T. Cauchy, O. Maury, Y. Le Gal, S. Golhen, O. Cador and L. Ouahab, Chem. Eur. J., 2010, 16, 11926-11941; (d) F. Pointillart, A. Bourdolle, T. Cauchy, O. Maury, Y. Le Gal, S. Golhen, O. Cador and L. Ouahab, Inorg. Chem., 2012, 51, 978984; (e) F. Pointillart, B. Le Guennic, S. Golhen, O. Cador, O. Maury and L. Ouahab, Inorg. Chem., 2013, 52, 1610-1620; (f) Y.-F. Ran, M. Steinmann, M. Sigrist, S.-X. Liu, J. Hauser and S. Decurtins, C. R. Chim., 2012, 15, 838-844; (f) G. Lapadula, D. Trummer, M. P. Conley, M. Steinmann, Y.-F. Ran, S. Brasselet, Y. Guyot, O. Maury, S. Decurtins, S.-X. Liu, C. Copéret, Chem. Mater., 2015, 27, 2033-2039.

16 (a) F. Pointillart, Y. Le Gal, S. Golhen, O. Cador and L. Ouahab, Chem. Eur. J., 2011, 17, 10397-10404; (b) F. Pointillart, S. Klementieva, V. Kuropatov, Y. Le Gal, S. Golhen, O. Cador, V. Cherkasov and L. Ouahab, Chem. Commun., 2012, 48, 714716; (c) F. Pointillart, B. Le Guennic, T. Cauchy, S. Golhen, O. Cador, O. Maury and L. Ouahab, Inorg. Chem., 2013, 52, 59785990; (d) G. Cosquer, F. Pointillart, S. Golhen, O. Cador and L. Ouahab, Chem. Eur. J., 2013, 19, 7895-7903; (e) T. T. da Cunha, J. Jung, M.-E. Boulon, G. Campo, F. Pointillart, C. L. M. Pereira, B. Le Guennic, O. Cador, K. Bernot, F. Pineider, S. Golhen and L. Ouahab, J. Am. Chem. Soc., 2013, 135, 16332-16335; (f) F. Pointillart, K. Bernot, S. Golhen, B. Le Guennic, T. Guizouarn, L. Ouahab and O. Cador, Angew. Chem. Int. Ed., 2015, 54, 1504-1507; (g) F. Pointillart, J. Jung, R. Berraud-Pache, B. Le Guennic, V. Dorcet, S. Golhen, O. Cador, O. Maury, Y. Guyot, S. Decurtins, S.-X. Liu and L. Ouahab, Inorg. Chem., 2015, 54, 5384-5397; (h) F. Gao, X.-M. Zhang, L. Cui, K. Deng, Q.-D. Zeng and J.-L. Zuo, Scientific Rep. 2014, 4, 5928.

17 (a) F. Pointillart, B. Le Guennic, S. Golhen, O. Cador, O. Maury and L. Ouahab, Chem. Commun., 2013, 49, 615-617; (b) K. Soussi, J. Jung, F. Pointillart, B. Le Guennic, B. Lefeuvre, S. Golhen, O. Cador, Y. Guyot, O. Maury, and L. Ouahab, Inorg. Chem. Front., 2015, 2, 1105-1117.

18 J. Wu, N. Dupont, S.-X. Liu, A. Neels, A. Hauser, S. Decurtins, Chem. Asian J., 2009, 4, 392-399.

19 M. Feng, F. Pointillart, B. Lefeuvre, V. Dorcet, S. Golhen, O. Cador and L. Ouahab, Inorg. Chem., 2015, 54, 4021-4028.

20 M. F. Richardson, W. F. Wagner and D. E. Sands, J. Inorg. Nucl. Chem., 1968, 30, 1275-1289.

21 K. Kodama, A. Kobayashi and T. Hirose, Tetrahedron Lett., 2013, 54, 5514-5517.

22 SHELX97 - Programs for Crystal Structure Analysis (Release 97. 2). G. M. Sheldrick, Institüt für Anorganische Chemie der Universität, Tammanstrasse 4, D-3400 Göttingen, Germany, 1998. SIR97 - A. Altomare, M. C. ; Burla, M. Camalli, G. L. Cascarano, C. Giacovazzo, A. Guagliardi, A. G. G. Moliterni, G. Polidori and R. Spagna, J. Appl. Cryst., 1999, 32, 115-119.
23 M. J. Frisch, G. W. Trucks, H. B. Schlegel, G. E. Scuseria, M. A. Robb, J. R. Cheeseman, G. Scalmani, V. Barone, B. Mennucci, G. A. Petersson, H. Nakatsuji, M. Caricato, X. Li, H. P. Hratchian, A. F. Izmaylov, J. Bloino, G. Zheng, J. L. Sonnenberg, M. Hada, M. Ehara, K. Toyota, R. Fukuda, J. Hasegawa, M. Ishida, T. Nakajima, Y. Honda, O. Kitao, H. Nakai, T. Vreven, Jr. J. A. Montgomery, J. E. Peralta, F. Ogliaro, M. Bearpark, J. J. Heyd, E. Brothers, K. N. Kudin, V. N. Staroverov, R. Kobayashi, J. Normand, K. Raghavachari, A. Rendell, J. C. Burant, S. S. lyengar, J. Tomasi, M. Cossi, N. Rega, J. M. Millam, M. Klene, J. E. Knox, J. B. Cross, V. Bakken, C. Adamo, J. Jaramillo, R. Gomperts, R. E. Stratmann, O. Yazyev, A. J. Austin, R. Cammi, C. Pomelli, J. W. Ochterski, R. L. Martin, K. Morokuma, V. G. Zakrzewski, G. A. Voth, P. Salvador, J. J. Dannenberg, S. Dapprich, A. D. Daniels, O. Farkas, J. B. Foresman, J. V. Ortiz, J. Cioslowski and D. J.; Fox, Gaussian 09 Revision A.02, Gaussian Inc., Wallingford CT, 2009.

24 J. P. Perdew, K. Burke and M. Ernzerhof, Phys. Rev. Lett., 1996, 77, 3865-3868; (b) C. Adamo and V. Barone, J. Chem. Phys., 1999, 110, 6158-6170.

25 M. Dolg, H. Stoll and H. Preuss, Theor. Chim. Acta, 1993, 85, 441-450.

26 F. Weigend and R. Ahlrichs, Phys. Chem. Chem. Phys., 2005, 7, 3297-3305.

27 J. Tomasi, B. Mennucci and R. Cammi, Chem. Rev., 2005, 105, 2999-3093.

28 (a) M. Cossi and V. Barone, J. Chem. Phys., 2001, 115, 47084717; (b) R. Improta, V. Barone, G. Scalmani and M. J. A. Frisch, J. Chem. Phys., 2006, 125, 054103-054109.

29 A.-R. Allouche, J. Comput. Chem., 2011, 32, 174-182.

30 F. Aquilante, L. De Vico, N. Ferré, G. Ghigo, P. A. Malmqvist, P. Neogrady, T. Bondo Pedersen, M. Pitonak, M. Reiher, B. O. Roos, L. Serrano-Andrés, M. Urban, V. Veryazov and R. Lindh, J. Comput. Chem., 2010, 31, 224-247.

31 B. O. Roos, P. R. Taylor and P. E. M. A. Siegbahn, Chem. Phys. $1980,48,157-288$

32 (a) P. A. Malmqvist, B. O. Roos and B. Schimmelpfennig, Chem Phys. Lett. 2002, 357, 230-240; (b) P. A. Malmqvist and B. O. Roos, Chem. Phys. Lett., 1989, 155, 189-194.

33 (a) L. F. Chibotaru and L. Ungur, J. Chem. Phys., 2012, 137, 064112-064122; (b) L. F. Chibotaru, L. Ungur and A. Soncini, Angew. Chem., Int. Ed., 2008, 47, 4126-4129.

34 F. Aquilante, P.-A. Malmqvist, T.-B. Pedersen, A. Ghosh and B. O. Roos, J. Chem. Theory Comput., 2008, 4, 694-702.

35 (a) B. O. Roos, R. Lindh, P.-A. Malmqvist, V. Veryazov, P.-O. Widmark, J. Phys. Chem. A, 2004, 108, 2851-2858; (b) B. O. Roos, R. Lindh, P.-A. Malmqvist, V. Veryazov and P.-O. Widmark, J. Phys. Chem. A, 2005, 109, 6575-6579; (c) B. O. Roos, R. Lindh, P.-A. Malmqvist, V. Veryazov, P.-O. Widmark and A.-C. Borin, J. Phys. Chem. A, 2008, 112, 11431-11435.

36 M. Llunell, D. Casanova, J. Cirera, J. M. Bofill, P. Alemany and S. Alvarez, S. SHAPE (version 2.1), Barcelona, 2013.

37 G. Cosquer, F. Pointillart, B. Le Guennic, Y. Le Gal, S. Golhen, O. Cador and L. Ouahab, Inorg. Chem., 2012, 51, 8488-8501.

38 X. Yi, K. Bernot, V. Le Corre, G. Calvez, P. Pointillart, O. Cador, B. Le Guennic, J. Jung, O. Maury, V. Placide, Y. Guyot, T. Roisnel, C. Daiguebonne and O. and Guillou, Chem.-Eur. J., 2014, 20, 1569-1576.

39 P. Goldner, F. Pell, D. Meichenin, F. Auzel, J. Lumin., 1997, 71, 137-150.

40 M. Feng, F. Pointillart, B. Le Guennic, B. Lefeuvre, S. Golhen, O. Cador, O. Maury and L. Ouahab, Chem. Asian J., 2014, 28142825.

41 (a) A. D'Aléo, A. Picot, A. Beeby, J. A. G. Williams, B.. Le Guennic, C. Andraud and O. Maury, Inorg. Chem., 2008, 47, 10258-10268; (b) F. Pointillart, O. Maury, Y. Le Gal, S. Golhen, O. Cador and L. Ouahab, Inorg. Chem., 2009, 48, 7421-7429; (c) A. Bourdolle, M. Allali, A. D' Aléo, P. L. Baldeck, K. Kamada, 
J. A. G. Williams, H. Le Bozec, C. Andraud and O. Maury, ChemPhysChem., 2013, 14, 3361-3367.

42 G. Cosquer, F. Pointillart, J. Jung, B. Le Guennic, S. Golhen, O. Cador, Y. Guyot, A. Brenier, O. Maury and L. Ouahab, Eur. J. Inorg. Chem., 2014, 69-82.

43 (a) C. Görlder-Walrand and K. Binnemans, Hanbook on the Physiscs and Chemistry of Rare Earths, 1996, 23, p. 121; (b) N. M. Shavaleev, G. Accorsi, D. Virgili, Z. R. Bell, T. Lazarides, G. Calogero, N. Armaroli, M. D. Ward, Inorg. Chem., 2005, 44, 6172.

44 O. Kahn, Molecular Magnetism; VCH: Weinhem, 1993.

45 (a) R. Orbach, Proc. Phys. Soc. A, 1961, 264, 458; (b) C. Rudowicz, J. Phys. C: Solid State Phys., 1985, 18, 1415.

46 (a) C. Dekker, A. F. M. Arts, H. W. Wijn, A. J. van Duyneveldt and J. A. Mydosh, Phys. Rev. B, 1989, 40, 11243; (b) K. S. Cole and R. H. Cole, J. Chem. Phys., 1941, 9, 341.

47 A. Abragam and B. Bleaney, Electron paramagnetic Resonance of Transition ions, Dover Publications, INC: New York, 1986.

48 (a) J. Jung, T. T. da Cunha, B. Le Guennic, F. Pointillart, C. L. M. Pereira, J. Luzon, S. Golhen, O. Cador, O. Maury and L. Ouahab, Eur. J. Inorg. Chem., 2014, 3888-3894.

49 (a) K. S. Pedersen, J. Dreiser, H. Weihe, R. Sibille, H. V. Johannesen, M. A. Sørensen, B. E. Nielsen, M. Sigrist, H. Mutka, S. Rols, J. Bendix and S. Piligkos, Inorg. Chem., 2015, 54, 7600-7606; (b) J. M. Zadrozny and J. R. Long, J. Am. Chem. Soc., 2011, 133, 20732-20734; (c) D. E. Freedman, W. H. Harman, T. D. Harris, G. H. Long, C. J. Chang and J. R.; Long, J. Am. Chem. Soc., 2010, 132, 1224-1225.

50 L. Tesi, A. Lunghi, M. Atzori, E. Lucaccini, L. Sorace, F. Totti and R. Sessoli, Dalton Trans. DOI: 10.1039/C6DT02559E.

51 A. Lunghi and F. Totti, Inorganics, 2016, 4, 28-38. 